\title{
Marine Plastic Debris: A New Surface for Microbial Colonization
}

\author{
Robyn J. Wright, ${ }^{\nabla}$ Gabriel Erni-Cassola, ${ }^{\nabla}$ Vinko Zadjelovic, Mira Latva, and Joseph A. Christie-Oleza*
}

Cite This: Environ. Sci. Technol. 2020, 54, 11657-11672

Read Online

ABSTRACT: Plastics become rapidly colonized by microbes when released into marine environments. This microbial community - the Plastisphere-has recently sparked a multitude of scientific inquiries and generated a breadth of knowledge, which we bring together in this review. Besides providing a better understanding of community composition and biofilm development in marine ecosystems, we critically discuss current research on plastic biodegradation and the identification of potentially pathogenic "hitchhikers" in the Plastisphere. The Plastisphere is at the interface between the plastic and its surrounding milieu, and thus drives every interaction that this synthetic material has with its environment, from ecotoxicity and new links in marine food webs to the fate of the plastics in the water column. We conclude that

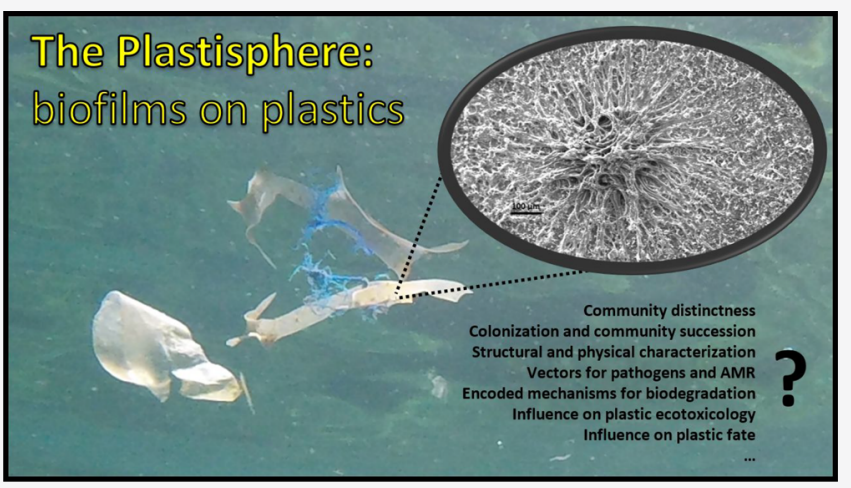
research so far has not shown Plastisphere communities to starkly differ from microbial communities on other inert surfaces, which is particularly true for mature biofilm assemblages. Furthermore, despite progress that has been made in this field, we recognize that it is time to take research on plastic-Plastisphere-environment interactions a step further by identifying present gaps in our knowledge and offering our perspective on key aspects to be addressed by future studies: (I) better physical characterization of marine biofilms, (II) inclusion of relevant controls, (III) study of different successional stages, (IV) use of environmentally relevant concentrations of biofouled microplastics, and (V) prioritization of gaining a mechanistic and functional understanding of Plastisphere communities.

\section{INTRODUCTION}

It is difficult to imagine living in the pre-"Plastic Era" where plastics were unknown to society, food was not packaged in films, and toys were made out of wood or metal. Plastics are extremely durable, lightweight, cheap, and versatile, characteristics which have led them to replace traditional materials (i.e., paper, metal, glass, and wood). Plastics have become a major commodity in our society, comparable to electricity or the Internet, but, beyond all of the benefits, these cheap materials have also encouraged the "throw-away" consumer culture which has evoked vast social and ecological issues. Despite growing awareness, over 300 million tons of plastic waste are still generated annually and the majority is not recycled after disposal. ${ }^{1}$ Plastic waste is a major environmental problem when it is not managed effectively. It is predicted that between 4.8 and 12.7 million tons of plastics enter the oceans annually, which is likely to continue to increase by an order of magnitude within the next decade. ${ }^{2}$ While plastics have been detected in almost every environment, those within aquatic ecosystems are perhaps of most concern due to their global transportability, e.g., by wind ${ }^{3}$ or ocean currents, ${ }^{4}$ reaching even uninhabited parts of our planet. $^{5-8}$

As with any kind of surface that enters aquatic environments, plastic debris rapidly becomes biofouled, i.e., colonized by living organisms that accumulate over time. ${ }^{9,10}$ The organisms that colonize plastic surfaces are microbial communities composed of diverse bacteria, single-celled algae, and fungi, but can also include macro-organisms such as barnacles, bryozoans, hydroids, or multicellular algae. ${ }^{1-15}$ These organisms that colonize buoyant marine plastic debris can be transported across the oceans and, in some cases, become invasive species of fragile ecosystems. ${ }^{16}$ While macroorganisms colonize only larger particles, microbial biofilms can develop on any surface, including smaller plastic particles under $1 \mathrm{~mm}$ in size, i.e., "microplastics". ${ }^{17}$ The microbial biofilms that form on plastic have been coined the "Plastisphere", 12 although this term does not imply that these polymeric materials are "actively" selecting for a distinctive microbial community because, as we discuss, this remains unproven.

All marine plastic debris will have a biofilm in the plasticseawater interface, and, hence, this living film will condition the way these materials interact with their surrounding environ-

Received: April 13, 2020

Revised: September 2, 2020

Accepted: September 3, 2020

Published: September 4, 2020

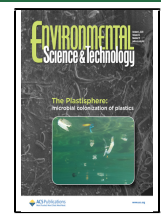




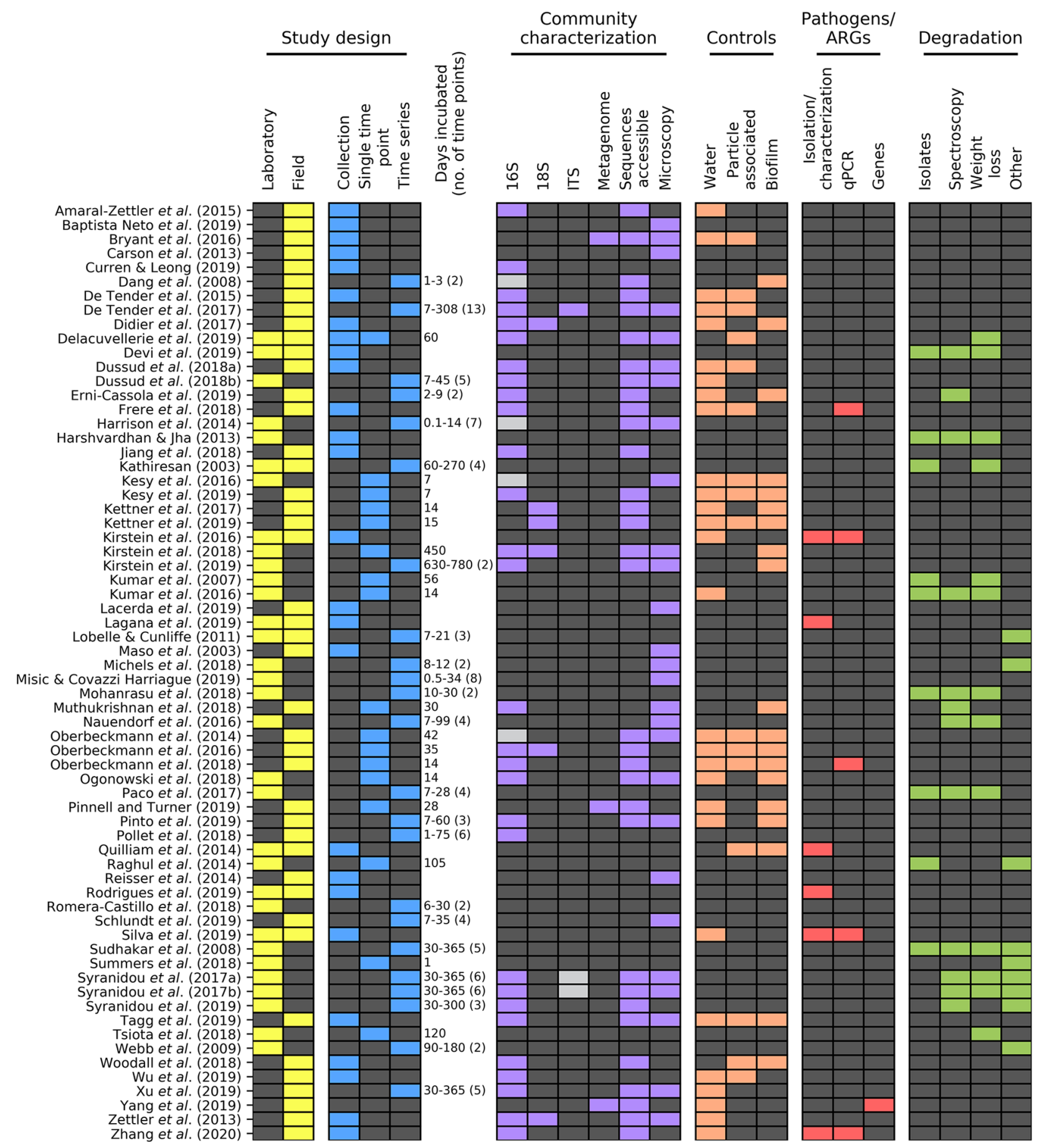

Figure 1. Literature review of 66 studies $^{12,14,44-53,35,54-63,37,64-73,38,74-83,39,84-93,40,94-98,41-43}$ that analyzed the Plastisphere on marine plastic debris. Study design highlights whether the study was conducted in a laboratory or in the field (yellow) and whether the plastic was naturally collected from the sea (collection) or introduced by the researchers and collected either at a single time point or at a series of time points (blue). Numbers indicate the first and last days of incubation, with numbers in brackets indicating the number of points included in the time series. Community characterization (purple) indicates whether the Plastisphere was analyzed via PCR amplicon analysis (16S, 18S, or ITS rRNA by high throughput sequencing in purple, or by TRFLP or ARISA in light gray) or whole metagenome sequencing, and whether microscopy was used to visualize the biofilm. Those studies that have made the sequencing data publicly accessible are also indicated. The controls (orange) highlight those studies that compare the Plastisphere with the microbial community of the surrounding seawater (either bulk or between 0.2 and $3 \mu \mathrm{m}$ ) or particulate organic matter $(>3 \mu \mathrm{m})$, or biofilms that develop on inert surfaces (e.g., glass, rock, wood, etc.). The pathogens/ARGs heading (red) indicates those studies where the presence of pathogens or antimicrobial genes was analyzed in the Plastisphere by obtaining isolates and characterizing their susceptibility to antibiotics, quantifying the presence of antibiotic resistance genes by qPCR, or identifying specific genes for pathogenesis by sequencing (genes). The degradation heading (green) shows those studies that aimed to determine plastic biodegradation via the isolation of microbial biodegraders or by analyzing the degradation of the plastic (Raman/FTIR spectroscopy, weight loss or another method, e.g., change in buoyancy or hydrophobicity). Further information including summaries of aims and key findings, materials tested, primers used, and sequencing accession numbers, is available in SI Table 1. 
ments. In this review, we highlight the importance of taking the Plastisphere into account when studying plastic sinks and ecotoxicology and discuss how marine plastic debris has become a new ecological niche within marine ecosystems. As the Plastisphere community composition and its role in plastic biodegradation has been discussed in recent reviews, ${ }^{18-22}$ we focus here on other aspects that we believe merit closer consideration, such as microbial community succession and biofilm-mediated interactions, and we offer our perspective with suggestions for future research in this field.

\section{THE CHALLENGES OF STUDYING BIOFILMS}

Biofilms are inherent to almost any surface in nature and are, in many cases, an unsolved problem to industry. ${ }^{23}$ Biofilms are highly persistent microbial communities that are able to resist adverse conditions thanks to the development of complex 3D structures and extracellular polymeric substances (EPS). ${ }^{24-27}$ Total DNA extraction and high-throughput sequencing has been an enormous step forward in determining community composition and function, but these are relative and not absolute measurements, and measurements are therefore compositional. $^{28}$ While cell and biomass quantification is relatively simple and straightforward for planktonic systems, absolute quantification has not been completely resolved for microbes growing in aggregates or on surfaces. ${ }^{29}$

How can we monitor microbial growth in a biofilm? DNA quantification can be used as a proxy for microbial growth, as recently demonstrated (e.g., refs 30 and 31); this can be particularly useful if it is already being carried out for molecular analyses, although it also may overestimate growth due to extracellular DNA and the presence of dead cells. ${ }^{32}$ Protein quantification, as well as the measurement of metabolic activity via colorimetric methods, have also been used as high throughput techniques for biomass monitoring. ${ }^{29} \mathrm{We}$, however, found them to be highly variable even within technical replicates, most likely due to small particles interfering with purification and downstream absorbancebased methods. ${ }^{31}$ A more sophisticated technique would involve quantifying the amplification of universal marker genes by qPCR (e.g., using the $16 \mathrm{~S}$ rRNA gene to quantify the prokaryotic community), although the accuracy of this method will depend on the efficiency of the primers used for universal amplification and the gene copy number per cell can be variable. The $16 \mathrm{~S}$ rRNA gene copy number can vary between one and 15 in some bacteria, and up to hundreds of $18 \mathrm{~S}$ rRNA gene copies can be found in some microbial eukaryotes. While this variability can be corrected for, ${ }^{33}$ some researchers advocate against these normalization approaches due to their lack of accuracy. ${ }^{34}$ Imaging through light, fluorescence, confocal, or electron microscopy is also a powerful method for monitoring biofilm growth, allowing not only the observation of surface coverage but also the observation of biofilm structures and microbial associations. ${ }^{35}$ Absolute biomass quantification by determining biofilm thickness, however, is only possible through confocal microscopy, proving complex and time-consuming. ${ }^{29}$ In our opinion, a combination of the above methods would be optimal for accurately quantifying biofilm growth, although the large investment of time required represents a handicap for routine implementation in Plastisphere studies.
THE PLASTISPHERE: "JUST" A NORMAL BIOFILM, BUT ON PLASTIC?

Microbial biofilms rapidly develop on any surface where water, nutrients, and a source of carbon and energy are available. These elements, as well as other physicochemical conditions such as salinity, temperature, or solar irradiation, are much more likely to condition the Plastisphere than the surface itself. $^{21}$ Due to their inertness, most plastics will have a negligible influence on the microbial community that colonizes them. In fact, it is now becoming increasingly clear that the bulk of microorganisms colonizing plastics are likely the same as would colonize any surface, artificial or natural. ${ }^{21}$ It is well established that the vast majority of planktonic microbes that populate the marine water column will strongly diverge from those able to associate and form biofilms. ${ }^{36}$ Thus, comparing the Plastisphere with the bulk seawater community may no longer be necessary. In fact, specialized planktonic organisms with streamlined genomes avoid adhesion and aggregation as a strategy to reduce their sinking rate. We strongly recommend though, that all Plastisphere studies include comparable inert control materials, such as glass, ceramic, shells, or-perhaps not so inert-wood, especially when testing hypotheses about the distinctiveness of marine plastics in specific processes (such as in the transport of pathogens, antimicrobial resistance genes, or potential polymer biodegraders).

This critical review emerges from a thorough literature search during which we assessed different studies for their objectives, use of controls, and methodologies used to characterize the microbial biofilm that develops on marine plastic debris (Figure 1 and Supporting Information (SI) Table S1). Our analysis revealed that only 19 of the 66 reviewed studies included a comparable inert control material, while 28 of them included a planktonic sample (generally defined as the seawater cellular fraction $<3 \mu \mathrm{m}$ ) and 16 included a particleassociated control (generally defined as $>3 \mu \mathrm{m}$ ). For those 19 that included a comparable inert control material, 14 reported differences between the control and the plastic (SI Table S1). These results nevertheless need to be taken with caution, because (I) the strongest differences between materials occur at the very early stages of colonization and are largely influenced by the presence of additives or preweathering of the material; $^{37,38}$ (II) environmental variables have a much larger influence on the community composition than plastic/material type; ${ }^{39-43}$ and (III) differences between materials are usually driven by rare taxa while abundant microbial groups remain largely unchanged. ${ }^{44,45}$ While specific microbial species are "actively" selected for in the rhizospheres and phyllospheres of plants, or in the gut microbiomes of humans and animals, it remains questionable whether plastics really are selecting for specific microbial communities. The mixed results obtained to date (SI Table S1) do not support such a conclusion. Thus, current understanding of microbial ecology leads us to believe that targeted selection would only occur if specific taxa from the Plastisphere could utilize the plastic as a source of carbon, i.e., the residual additives or polymeric residues. This occurs rarely, and hence, the biofilms that develop on these synthetic materials will not be any different from the ones that develop on any other surface under similar physicochemical conditions.

\section{WHAT FEEDS AND SHAPES THE PLASTISPHERE?}

The hopeful idea that Plastispheres can grow by mineralizing plastic has dimmed for obvious reasons, such as the extreme 
recalcitrance of these materials, ${ }^{20,21,99}$ as well as discussed in detail below. How then does the Plastisphere develop on marine plastic debris? Here, we discuss the three key elements required to support any form of life, i.e., water, nutrients, and energy, and how they are obtained by the Plastisphere.

Water. This element is, of course, not limiting for submerged plastics in marine ecosystems. Nevertheless, materials that become stranded on shorelines are severely affected and, in fact, very little life can develop on plastics that are above the tidal line. Another interesting and unexplored aspect is the remarkable adaptation of microbes to the salinity of seawater, and thus, the variations that may occur in the Plastisphere of riverine borne plastics as they transition into marine conditions. While some microbes can temporarily resist the $3 \%$ salt of seawater, durable growth, and life in marine conditions requires profound evolutionary adaptations. ${ }^{100} \mathrm{~A}$ drastic change in community composition in plastics moving from freshwater to seawater environments would therefore be expected.

Nutrients. Sunlit oceans are highly oligotrophic, i.e., low in nutrients. Oceans transition from mesotrophic in coastal areas to ultraoligotrophic in subtropical gyres. ${ }^{101}$ As currents transport plastics, they converge in all five oceanic gyres, known as plastic hotspots or garbage patches; ${ }^{5}$ a significant proportion of marine plastic debris is therefore exposed to ultraoligotrophic conditions. While planktonic organisms have evolved fascinating mechanisms to overcome such deprivation of nutrients, ${ }^{102-104}$ these may be dispensable for microbes within biofilms. The intimate closeness of microbes within biofilms increases the number of interactions as well as the entrapment of nutrients obtained from their oligotrophic surroundings. Thus, while planktonic organisms living in immensely dilute systems rely on distant and transient microbe-microbe exchange of nutrients, ${ }^{105}$ the build-up and cycling of nutrients between phototrophic and heterotrophic microorganisms within biofilms is much more effective. It is therefore not surprising to find that Plastispheres are more productive than their surrounding planktonic counterpart communities. ${ }^{48}$ As a proof of concept, we showed that plastic exposed to recirculating oligotrophic seawater was able to develop a considerable biofilm-sustained by phototrophic organisms - and build up a substantial amount of organic carbon and nitrogen, the latter by impoverishing the surrounding water (Figure 2).

Energy. The source of energy to power the Plastisphere will mainly depend upon the position of the plastic within the water column. Plastics segregate in the water column depending on the material's density (Figure $3 \mathrm{~A}^{106}$ ), although the Plastisphere may also play an important role in determining the position of plastics in the water column (Figure 3B and further discussed below). Buoyant plastics in the photic layers of the oceans are colonized by photosynthetic primary producers ${ }^{12,48}$ that empower the Plastisphere through the production of labile photosynthate. The availability of this labile source of carbon and energy will facilitate the development of large biofilms that specialize in the use of photosynthate, outcompeting any potential plastic-or plastic additive-biodegrading organism. In turn, denser polymeric materials that sink to aphotic layers, where light is insufficient for photosynthesis, will force the Plastisphere to obtain energy from degrading (I) compounds from its surrounding environment, (II) the biofilm itself, causing a reduction in the Plastisphere's size (Figure 3B), or (III) the plastic-or

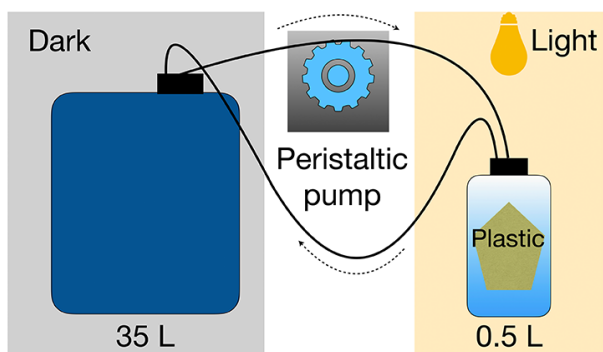

Water

(a)

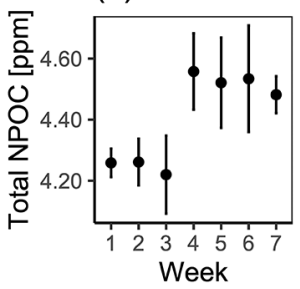

(c)

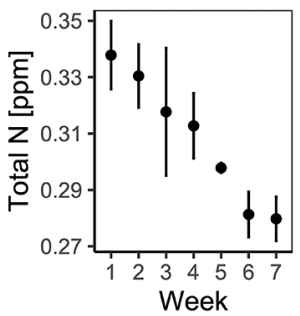

Plastic

(b)

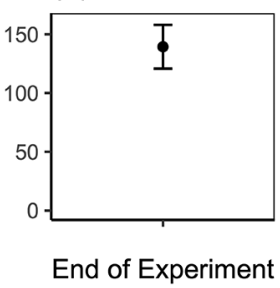

(d)

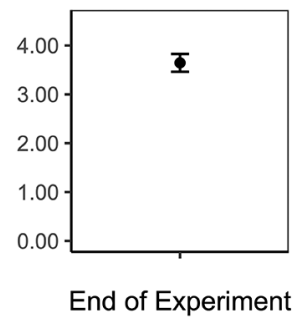

Figure 2. Nutrient dynamics between natural oligotrophic seawater and plastic on which a biofilm builds up. A communicating vessel setup (top scheme) was used to recirculate seawater from the main $\operatorname{tank}(35 \mathrm{~L}$ and kept in the dark) through a $0.5 \mathrm{~L}$ glass vessel containing a fragment of a commercial plastic bag (PE; $38 \times 47 \mathrm{~mm})$ that was exposed to light. The flow rate was kept at $70 \mathrm{~L}_{\text {week }}{ }^{-1}$. Nutrient measurements were determined weekly for the seawater $(a, c)$ and at the end of the experiment for the plastic $(b, d)$. Nonpurgeable organic carbon (NPOC) and total nitrogen (N) were measured using a TOC-L CPH/TNM (Shimadzu). Values represent measurement mean ( \pm standard error) from three independent replicates. Note that scales differ between subplots.

additives/monomeric constituents of (discussed below)they are colonizing.

\section{SUCCESSION IN THE PLASTISPHERE: FROM PRIMARY COLONIZATION TO BIOFILM MATURITY}

The analysis of Plastispheres collected from the ocean are snapshots of plastic colonization at unknown time points, but how relevant is time in the Plastisphere's composition? More controlled studies of the Plastisphere, where pristine plastics were incubated in natural seawater and sampled at different time points, have shown that there are strong shifts and distinct communities between treatments during early stages of colonization. Over time, however, communities converge and remain stable in mature biofilms (SI Table $\left.\mathrm{S} 1 ;{ }^{15,37,38,58,60,64,81,91}\right)$. But what "early stages" of colonization are, will depend on the growth rate of the biofilm, determined by factors including temperature, light, and nutrient availability. In our experience, a stable and consistent Plastisphere can be achieved within days to just over 1 week (Figure $4 ;^{37}$ ), although the establishment of a mature eukaryotic community 
A

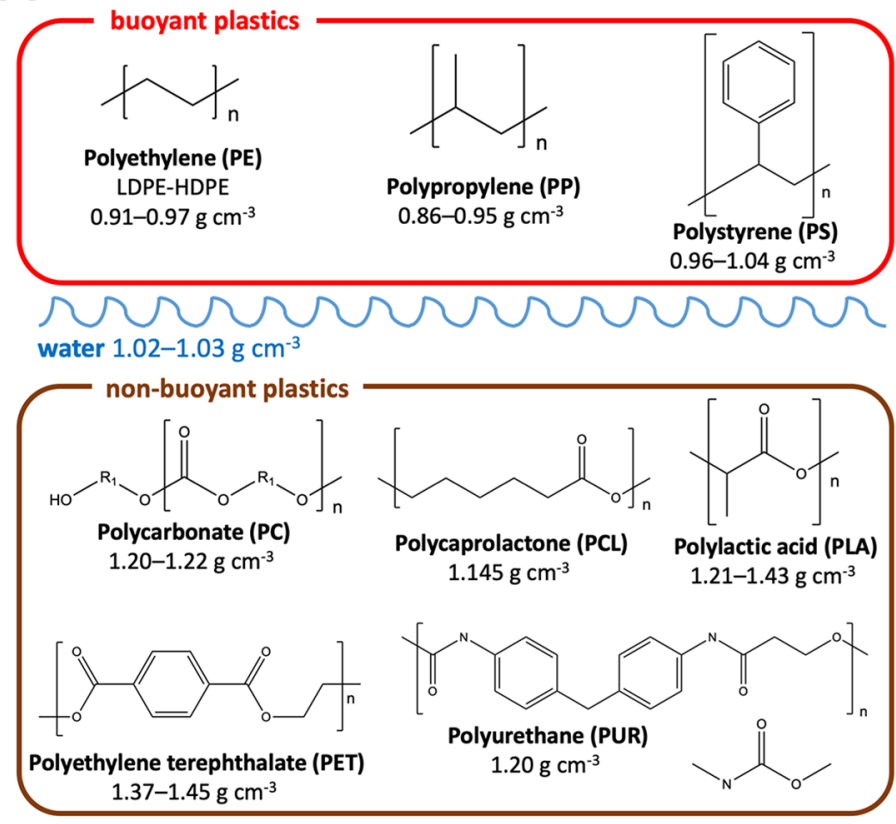

B
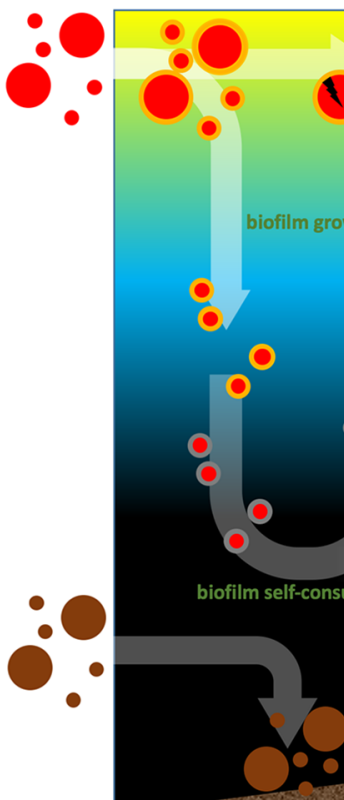

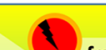
fragmentation

Light
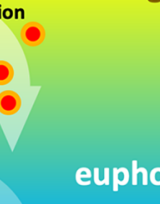

euphotic
?

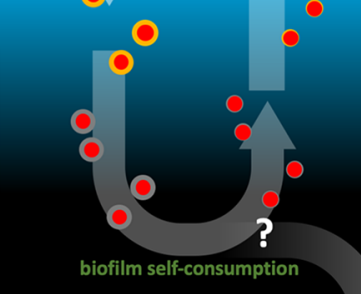

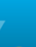

(2)

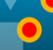

○

Figure 3. Distribution of different polymer types within the water column attending to the material's density. (a) Examples of buoyant and nonbuoyant plastics. Material densities are indicated in $\mathrm{g} \mathrm{cm}^{-3}$. (b) Hypothetical movement of buoyant (red) and nonbuoyant particles (brown) as they enter marine ecosystems. Plastispheres with (orange) and without (gray) phototrophic microbes are indicated. The oscillatory sinkingresurfacing of small buoyant plastics as the Plastisphere develops and self-consumes in euphotic and aphotic layers, respectively, is represented as previously suggested by Kooi et al. ${ }^{107}$

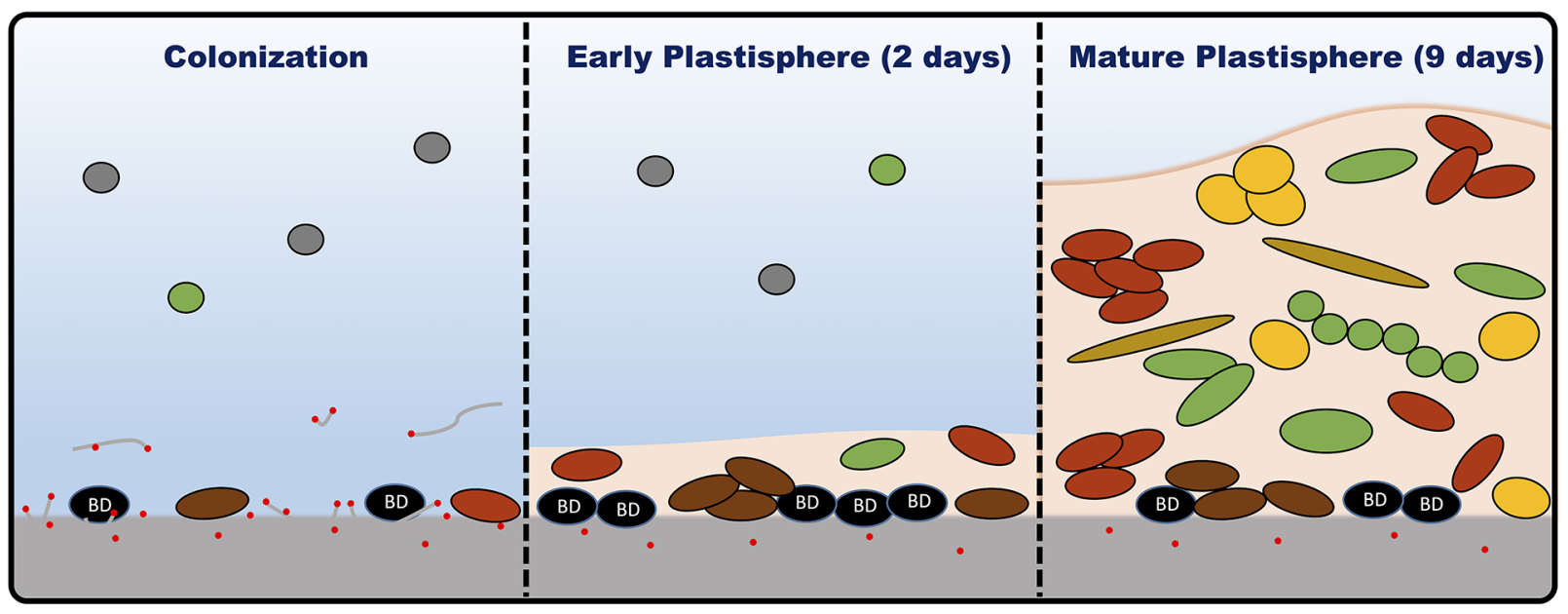

Figure 4. Abstract representation of plastic colonization in seawater. Biodegrading microbes (BD) are represented in black. These may pioneer the colonization of surfaces, especially if oligomers and plastic additives are available as a source of carbon and energy. Once this source is depleted, BD will be outcompeted by specialized microbes able to grow using the labile photosynthate produced by photosynthetic microbes (green).

may take longer. ${ }^{108}$ The concept in microbiology that "everything is everywhere, but the environment selects", 109,110 together with an element of stochasticity, may well apply to plastic colonization in marine environments. Microbes from the rare marine biosphere, usually copiotrophic microorganisms, cannot compete with the major groups of specialized planktonic microbes that thrive under natural ultraoligotrophic seawater conditions. These low abundance copiotrophs are nevertheless able to rapidly bloom under specific conditions, taking advantage of the heterogeneity of nutrient patches in marine systems, ${ }^{111,112}$ such as when a fecal pellet releases high amounts of nutrients or, in this case, a surface becomes available for colonization.
The high hydrophobicity of plastics produces a strong interface when these materials are put in water, hindering microbial attachment. Nevertheless, these surfaces are rapidly covered by organic matter, collectively referred to as the ecocorona, ${ }^{113}$ which decreases the hydrophobicity of the surfaces and facilitates microbial colonization. In fact, our preliminary data as well as Harrison et al. ${ }^{60}$ suggests that microbial attachment to plastics in marine environments occurs within minutes. Like any primary colonization of a pristine uninhabited environment, there is an initial "stochastic" proliferation of generalist organisms under no competition other than to grow faster than the rest to cover the maximum possible surface area. After this initial colonization, resources 
and space become limiting and microbes diverge into specific niches to avoid competition. As the biofilm matures and increases in complexity, it produces complex extracellular polymeric substances for protection and to reduce predation, as well as secondary metabolites for quorum sensing or to exert an antimicrobial effect on competing microbes (thoroughly reviewed previously ${ }^{25,36,114-116}$ ).

Pioneering microbes in the colonization of plastics may initially obtain energy from readily available polymeric oligomers generated from plastic weathering, ${ }^{37,85,117}$ or morelabile additives that leach out from pristine manufactured plastics. ${ }^{118}$ These initial sources of energy are nevertheless depleted within days, and a constant supply is favored over time, such as organic matter obtained from the seawater or photosynthate generated from other pioneering phototrophic organisms (Figure 4). In fact, diatoms, cyanobacteria, and green algae have been reported as pioneering microbes that colonize marine plastic debris. ${ }^{12,48}$ Interestingly, even if plastics were sufficiently labile to support microbial growth of the Plastisphere, we and others have shown that biodegradation of plastics would likely stall due to community succession. ${ }^{30,31,119}$ Using chitin-a naturally abundant and biodegradable polymer in marine ecosystems - to study particle biodegradation, it was shown that colonization occurs in remarkably distinct stages of succession: (I) stochastic attachment/colonization of pioneering microbes, where the most abundant organisms are those capable of efficient surface adhesion; (II) selection, where organisms capable of degrading the polymer become enriched; and (III) succession, during which the degraders are overtaken by grazers, viruses, cross-feeders, and "cheaters". ${ }^{30,31,119,120}$ In these studies, chitin degradation dropped to negligible values as chitin-degrading microbes became outcompeted by others in mature biofilms, suggesting the same may well occur to any potential plastic biodegrading microbes in the Plastisphere.

\section{BIOFOULING AND PLASTIC BUOYANCY: COULD THE PLASTISPHERE EXPLAIN THE UNACCOUNTED FRACTION OF PLASTICS?}

Numerous studies have now reported that there is a large disparity between the quantity of plastic predicted to have entered the oceans and the amount measured by monitoring studies, sometimes referred to as the "missing 99\%".,121 Multiple sinks for this "missing" plastic are likely, but one suggestion is that biofouling and ingestion may play a role in the vertical transport of plastics from the surface to deeper waters. ${ }^{5}$ Plastics can segregate in the water column according to the material's density, ${ }^{106}$ but once biofouled, the overall density may change, causing the sinking of a priori buoyant materials. It has been well reported that large buoyant plastics sink when biofouled by marine macro-organisms, such as hydroids, barnacles, bryozoans, or brown, green, and red algae. $^{122-125}$ Some of these organisms, e.g., calcareous barnacles and mussels are unlikely to be able to grow extensively on submillimeter size particles though, ${ }^{124}$ and therefore, microplastics are mostly colonized by prokaryotic and eukaryotic microorganisms, as discussed above. Microbial colonization may increase the density of buoyant plastics. ${ }^{123,126,127}$ Some primary colonizing microbes, such as diatoms, ${ }^{12}$ have dense silica shells, but bacteria are also denser than seawater and may cause the sinking of buoyant plastics. Nevertheless, the absence of accurate experimental measurements-i.e., realistic Plastisphere thickness and density values-complicates current sinking models.

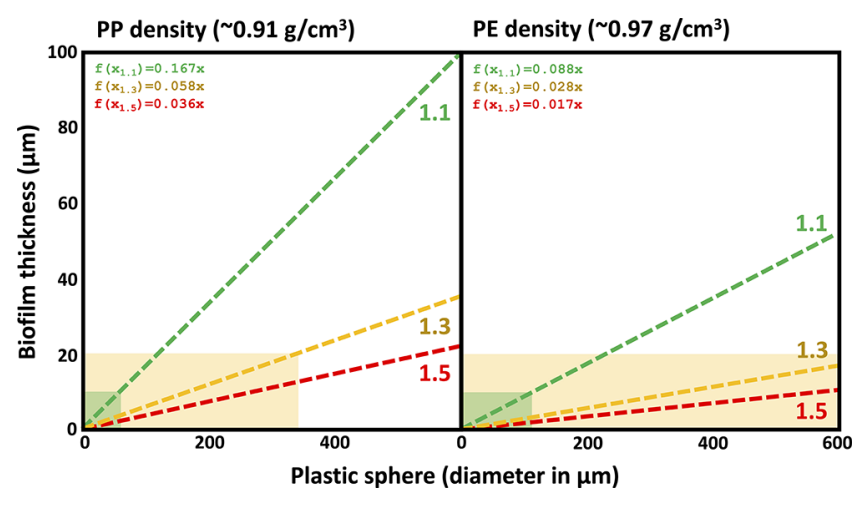

Figure 5. Model representing the characteristics of the biofilmthickness ( $Y$-axis) and density (three dotted lines representing biofilm densities of $1.1,1.3$, and $1.5 \mathrm{~g} \mathrm{~cm}^{-3}$ ) required to cause a spherical buoyant plastic (polypropylene, PP, left; polyethylene, $\mathrm{PE}$, right) to become neutrally buoyant in seawater $\left(1.02 \mathrm{~g} \mathrm{~cm}^{-3}\right)$. Realistic and likely scenarios are shaded in green and orange, respectively.

What is the upper size limit for a buoyant microplastic to sink as a result of microbial colonization? Figure 5 shows an attempt to determine this size while maintaining realistic biofilm thickness and corresponding biofilm density. By fixing biofilm density to $1.1 \mathrm{~g} \mathrm{~cm}^{-3}$ and biofilm thickness to $10 \mu \mathrm{m}$, we suggest that only spherical polyethylene particles (density, $\delta$ $=0.97 \mathrm{~g} \mathrm{~cm}^{-3}$ ) with diameters below $114 \mu \mathrm{m}$ and polypropylene particles (density, $\delta=0.91 \mathrm{~g} \mathrm{~cm}^{-3}$ ) below 60 $\mu \mathrm{m}$ would sink out of surface seawaters (Figure 5). These values may explain why microbial biofouling alone was not enough to induce sinking of $1 \mathrm{~mm}$ sized PE particles incubated in coastal and estuarine locations. ${ }^{125}$ They also support studies that show how polypropylene dominates the smaller fractions of microplastics, ${ }^{128,129}$ while polyethylene materials are predominant among macro-plastic found on seawater surfaces. ${ }^{130}$ The oversimplified calculations presented here (Figure 5) require further work; for example, the inclusion of particle shapes, other than spheres, which will increase the colonization surface to plastic volume ratio. The point, nevertheless, is that without experimental measurements, e.g., of Plastisphere thickness and density in natural marine environments, the disparity of variables does not allow accurate predictions.

If the Plastisphere is able to increase the density of small buoyant microplastics, removing them from the sea surface, would this explain the "missing 99\%" of buoyant plastics described from marine surveys? ${ }^{121}$ More importantly, does the Plastisphere "drag" these buoyant plastics all the way down to the deep-sea sediments, where they may be buried, or will they oscillate, as suggested in Figure 3B? As mentioned above, biofilms-like any form of life-require a constant source of energy. Buoyant plastics that remain in the euphotic layers of the ocean will be colonized by thriving phototrophic microbes that feed the Plastisphere, but as soon as the particle sinks out of the euphotic layer and photosynthate is no longer produced, the biofilm will self-consume, reducing its size and, hence, regaining buoyancy. Ye and Andrady ${ }^{123}$ already suggested 30 years ago that biofouled marine plastics might be prone to recurrent cycles of sinking and resurfacing due to the defouling which occurs on submerged pieces when unable to sustain phototrophic communities, or when other organisms feed on the fouling community. This was modeled for microplastics by Kooi et al., ${ }^{107}$ showing that biofouling caused a loss in 

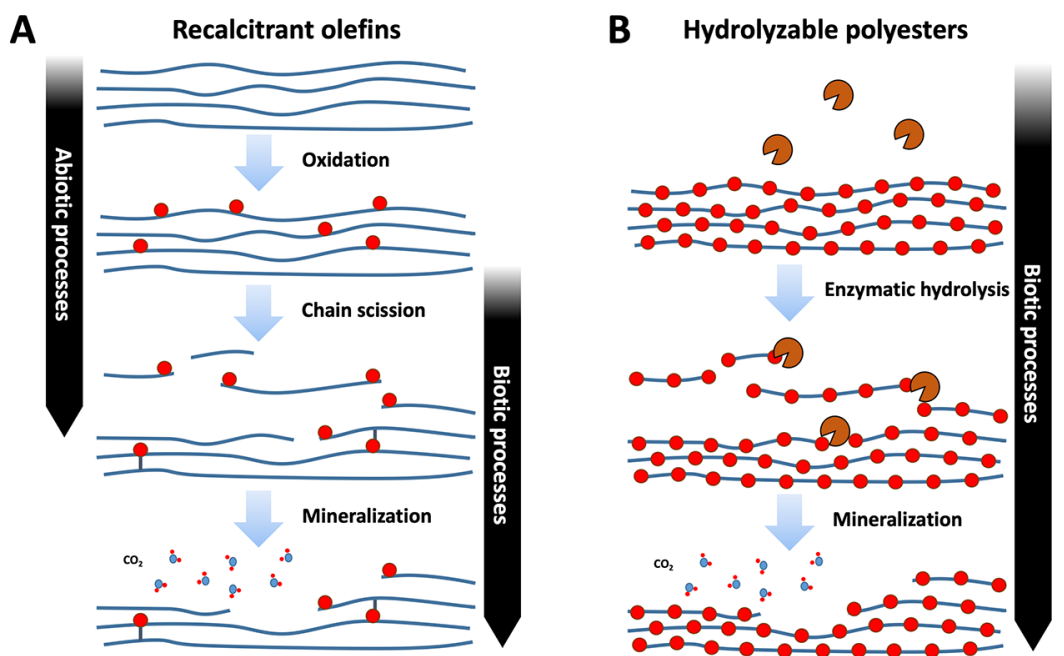

Figure 6. Steps required for recalcitrant (a) and hydrolyzable polymer degradation (b). Those steps that are most likely carried out by abiotic and biotic processes are highlighted. Blue lines represent polymeric chains and red circles represent oxygen groups. Hydrolytic enzymes are represented in brown.

buoyancy of plastics (i.e., HDPE, LDPE, PP; radius range 0.1 $\mu \mathrm{m}-10 \mathrm{~mm})$ which, instead of sinking to the ocean floor, oscillated in the water column. Field evidence likewise indicates that the highest concentrations of marine microplastics are found deeper in the water column (at depths of 200-600 m), rather than in surface waters, ${ }^{131}$ although the scarcity of buoyant polymer types reported by this study does not help to explain the ultimate fate of these plastics in the oceans.

While plastics have been found in every compartment of marine ecosystems, ${ }^{106}$ so far the Plastisphere has predominantly been analyzed in shallow marine waters where light is available and, most likely, becomes the main source of energy to the biofilm. The Plastisphere of only six fragments/fibers from the deep sea have been analyzed; ${ }^{132}$ PVC, PE, polyamide, and polyester. Further research is required to analyze the composition of the Plastisphere at different water depths, including aphotic layers and within sediments. An explanation for the findings of polymers less dense than seawater in the deep sea ${ }^{6,133}$ is the inclusion of microplastics in fecal pellets ${ }^{134-137}$ as well as entrapment in aggregates and marine snow. ${ }^{88,138-143}$ Entrapped buoyant plastics can also be released from these sinking particles, ${ }^{134}$ and unless buried in the sediment, will presumably resurface over time. Given this hypothetical vertical oscillation of plastics in the water column, compositional and structural analyses (e.g., biofilm thickness) should be performed on plastics transferred between different compartments, such as between photic and aphotic layers.

\section{DO RECALCITRANT PLASTICS SELECT FOR BIODEGRADING ORGANISMS IN THE NATURAL MARINE ENVIRONMENT?}

This is a challenging question that still remains unanswered due to (I) the intrinsic difficulty of recalcitrant polymer degradation (e.g., hydrophobicity, insolubility, crystallinity, and extremely high molecular weight of the polymers; ${ }^{144,145}$ ), and (II) the lack of irrefutable certainty when identifying microbes that can really mineralize plastics in marine systems, especially within complex biofilms. ${ }^{19}$ While labile materials such as some polyesters may provide a source of carbon and energy for the Plastisphere, the incredibly long timeframes required for microbial plastic biodegradation of more recalcitrant plastics-e.g., PE, PP, and PS-suggest that it is unlikely that these materials will select for degrading microbes unless they are preconditioned, as we discuss below. On the biodegradation of plastics, we agree with Oberbeckmann and Labrenz ${ }^{21}$ and here adopt the same definition, i.e., biodegradation is the total assimilation and mineralization of the synthetic polymers by the organisms.

The most abundantly manufactured plastics can be categorized into two groups when we consider their environmental properties: (I) nonbuoyant hydrolyzable (e.g., polyesters) and (II) buoyant nonhydrolyzable polymers (e.g., olefins such as PE and PP) (Figures 2 and 6). Polyesters, such as PET, can be biologically depolymerized via the hydrolysis of their ester bonds by the action of esterases, ${ }^{146,147}$ whereas enzymatic chain scission of the more refractory nonhydrolyzable polymers is more challenging as they present no reactive groups (Figures 3 and 6). Abiotic weathering processes (i.e., photooxidation and thermooxidation) are believed to be the main drivers of such oxidation, ${ }^{148}$ but biological redox reactions could also play an important role ${ }^{145}$ via enzymes such as oxidoreductases, monooxygenases, cytochrome P450s, hydroxylases, and laccases. ${ }^{18}$ Chemical oxidation of the polymeric chain is thought to occur randomly, generating a large diversity of short-chain scission products that then need to be mineralized to complete plastic degradation. While many studies consider alkane biodegradation as the "logical" pathway for olefin biodegradation (because PE consists of immensely high molecular weight alkanes), the chain scission products generated from the oxidation of PE are in fact most likely to be long-chain carboxylic and dicarboxylic acids. ${ }^{117,149}$ These intermediates, and to a lesser extent short alkanes, will be released from weathered $\mathrm{PE}$ as dissolved organic matter and will induce microbial growth. ${ }^{37,85}$ Hence, preweathered materials that initially release large amounts of oligomeric chains are likely to select for microbes that are able to biodegrade these subproducts. While plastics may attract specific microbes with determined biodegrading capabilities via chemical cues such as methane, ethane, and ethylene ${ }^{20,150}$ or oligomers that are generated from weathering, ${ }^{37,117}$ this is likely to be transient and will only occur within the first 
minutes or hours of plastic submersion. Once the initial source is depleted, biodegrading microbes will become outcompeted/ diluted within large mature biofilms (Figure 4; ${ }^{37,38,51,81}$ ). Mature Plastispheres may contain potential plastic degraders, although these are likely in the rare fraction that is in close proximity to the plastic surface. Hence, if the aim is to study plastic-degrading organisms, it may be a good idea to eliminate the mature biofilm and focus on the closely attached microbes at the very surface of the plastic, as previously done. ${ }^{45}$

Efficient degradation of olefin plastics requires the combined action of abiotic and biotic processes (Figure 6; e.g., refs 144 and 145), but initial steps of abiotic oxidation and chain scission may be delayed in marine plastic debris due to the lack of thermal oxidation and the screening action of the Plastisphere against solar radiation. ${ }^{151}$ Can biotic oxidation of plastics replace the lack of abiotic oxidation in seawater? Are biodegrading microbes present in close proximity to the plastic surface really breaking down the plastic? These questions remain unanswered and, for example, while it may be true that obligate hydrocarbonclastic bacteria (OHCB) that are highly specialized in hydrocarbon degradation might be degrading plastics when found in the Plastisphere, this continues to be an untested hypothesis.

The challenge of studying plastic biodegradation is that the entire process is too slow to be visualized through traditional microbiology methods such as microbial growth or substrate depletion. Different techniques have been employed to assert biodegradation, such as plastic weight loss, decrease of polymer chain length (via gel permeation chromatography, GPC), or surface oxidation (via X-ray photoelectron spectroscopy, XPS, or Fourier transform infrared spectroscopy, FT-IR; Figure 1). To some extent, all are valid measures of biological action on plastics, but definitive proof would require the use of isotopically labeled materials, as suggested by Zumstein et al. ${ }^{152}$ The implementation of stable isotope probing (e.g., ${ }^{13} \mathrm{C}$ labeled substrates) to identify those members of the Plastisphere that are able to degrade and assimilate the plastic via the incorporation of heavy carbon into the microbial DNA, i.e., DNA-SIP. ${ }^{153}$ While the use of ${ }^{13} \mathrm{C}$-labeled polyethylene has been used to show the transfer of polymeric carbon across freshwater food webs, ${ }^{154}$ it has still not been used for the identification of those microbes involved in the first steps of plastic biodegradation and assimilation. Nevertheless, in the environment, it is uncertain whether the assimilation of heavy carbon into the DNA of biodegrading organisms will occur fast enough before this carbon is leaked among the rest of the nondegrading community, resulting in the labeling of the entire community.

Does the presence of light and the supply of labile photosynthate diminish or enhance plastic biodegradation? When do maximum biodegradation rates occur and when is it best to isolate plastic-degrading microbes? These will remain unanswered questions until we determine the molecular mechanisms behind plastic biodegradation, which are currently unknown for recalcitrant olefins. The mechanistic characterization through the identification of the key enzymes involved will help inform currently mislead OMIC analyses. Maybe, more than taxonomical assessments, we should be characterizing processes within the Plastisphere to answer all of these unresolved questions. For this we need to go back to the bench in order to isolate microbes with true biodegrading potential, and to prove the mechanisms involved via traditional molecular biology and biochemistry. Some examples that endorse this statement are the discovery of the PET hydrolyzing enzyme, PETase, in Ideonella sakaiensis ${ }^{146}$ and our recent publication showing that an esterase, encoded by an Alcanivorax strain obtained from marine plastic debris, is able to hydrolyze both natural and synthetic polyesters. ${ }^{155}$ The discovery of these enzymes-and the protein sequences encoding them-means that they can be used to search global metagenomes which, in the case of the PETase, has already revealed the distinct taxa that possess similar enzymes in marine and terrestrial ecosystems. ${ }^{147}$ But which enzymes are involved in the biodegradation of recalcitrant olefins? What should we be searching for?

\section{THE PLASTISPHERE INTERFERES IN THE ECOTOXICOLOGY OF PLASTIC-BOUND CHEMICALS}

High molecular weight polymers that make up most plastics are generally inert, but as many as 906 additional chemicals have been associated with plastics. ${ }^{156}$ These chemicals can be split into additives, those that are added intentionally during manufacturing, ${ }^{157}$ and contaminants, those that sorb to the plastics once in the environment. ${ }^{158-160}$ These compounds are generally not covalently bound to the polymer and, thus, may sorb/desorb from plastics in equilibrium with the surrounding milieu. Hydrophobic chemicals have a high affinity for plastics and are found on the surfaces of plastics at up to $10^{6}$ times the concentration of the surrounding water. ${ }^{161} \mathrm{~A}$ large number of these chemicals are known for their toxicity to marine biota. ${ }^{159,162-165}$ The leaching of such highly concentrated toxic chemicals from plastics is believed to be a principal cause of plastic ecotoxicity.

It is not yet clear, though, to what extent chemicals from biofouled plastics even reach the surrounding milieu and become bioavailable to marine biota. The microbial degradation of such chemicals, e.g., plasticizers, has been reported since the 1950s. ${ }^{166}$ There are numerous studies on the terrestrial degradation of plasticizers, e.g., refs 167-169 and we recently characterized the biodegradation of these additives by microbes obtained from the Plastisphere of marine plastic debris. ${ }^{118}$ Does the Plastisphere therefore reduce the ecotoxicity of plastics? Future experiments testing the toxicity of plastic additives should consider including biofilms to simulate more close-to-environment conditions. In fact, we hypothesize that plastics may even act as hotspots of pollutant degradation as they facilitate the concentration of hydrophobic pollutants and encourage the development of specialized biodegrading microbes. Microbial growth, supported by such additives, may even lead to erroneous conclusions on plastic polymer biodegradation.

To our knowledge there are only two studies to date (Figure 1) that take either plastic additives or degradation subproducts into account; (I) Pinto et al. ${ }^{38}$ incubated PE, PP, and plasticized PVC (with diisononyl or diisodecyl phthalate) for up to two months and (II) in our previous study, Erni-Cassola et al., ${ }^{37}$ we incubated weathered and nonweathered PE for 2 or 9 days. While Pinto et al. ${ }^{38}$ measured the plasticizers before and after incubation, they did not report a decrease in concentrations and, also, did not incubate unplasticized PVC, and while we showed that oxidized polymer chains likely shed off weathered PE when in solution, we did not measure the concentration of these shorter polymer chains and oxidized subproducts. ${ }^{37}$ There are also, to our knowledge, very few studies (in any environment) that examine the influence of 
plastic additives on plastic degradation, and these results have been found to be dependent on the plasticizer in question. Labrecque et al. ${ }^{170}$ found that lower molecular weight plasticizers increased enzymatic PLA degradation rates, while higher molecular weight plasticizers actually decreased degradation rates (compared with unplasticized PLA). The impact of plastic additives and degradation subproducts on both shaping the Plastisphere and on plastic biodegradation therefore remains to be determined, and a possible toxic effect of these on Plastisphere communities, as we found for the plasticizer degradation intermediate phthalic acid on two marine bacterial isolates, ${ }^{171}$ should also be evaluated. Information on the additive content of plastics can often be difficult to obtain, ${ }^{156}$ but we nevertheless advocate for a more comprehensive consideration and reporting of the concentration of additives, contaminants, and degradation subproducts when carrying out any environmental plastics study.

\section{CAN PLASTICS BE CLAIMED AS SPECIFIC VECTORS OF PATHOGEN DISPERSAL?}

Several studies report that potentially pathogenic organisms are present on marine plastic debris (Figure 1), usually with a focus on the prevalence/abundance of Vibrio spp., e.g., ref 65. These latter microbes, however, are ubiquitous in marine environments, occurring in the water column as well as in biofilms on rocks, corals, or copepods. ${ }^{172}$ Indeed, studies that include nonplastic controls in their analyses (Figure 1) sometimes even report a higher proportion of potential pathogens, i.e., Vibrio spp., on control substrates than on the plastics themselves. ${ }^{41,65,82,173}$ While a paper reporting such results could be titled "plastics carry potentially pathogenic hitchhikers", perhaps it would be more accurate to state that "marine surfaces are colonized by potentially pathogenic hitchhikers". When discussing the results, authors could acknowledge that plastics have much higher durability, buoyancy, and therefore transportability than natural cooccurring materials, and thus, pose a higher risk due to prolonged exposure times or higher encounter rates. Here we discuss the main questions that must be addressed by future studies: (I) Are these potential pathogens indeed pathogenic? (II) Do pathogens accumulate on plastics and are there plasticspecific pathogens? (III) Do plastics act as vectors for pathogen dispersal?

Are These Potential Pathogens Indeed Pathogenic? The majority of ubiquitous marine Vibrio spp. are most likely harmless or even beneficial to some animals, such as the bioluminescent symbiont Vibrio fischeri with its squid host. ${ }^{174}$ Even isolates of the three pathogenic species $V$. cholerae, $V$. vulnificus, or $V$. parahaemolyticus require specific virulence factors in order to cause infections and this can only be determined by typing the subspecies. ${ }^{175-177}$ While high throughput sequencing of short fragments of marker genes (i.e., 16S rRNA gene) is an effective tool to characterize general microbial community structures, it does not allow robust identifications at the species level, and even less so at serotype level, ${ }^{178}$ meaning that the potential pathogens identified only at the genus level (e.g., Oberbeckmann et al. $^{41}$ ) as well as at the species level (e.g., Frere et al. ${ }^{59}$ ) require more robust testing to determine their actual pathogenesis. Furthermore, as reference databases are usually swamped with clinical pathogens (i.e., over half of the full prokaryotic genomes available in the NCBI database have a human host), this is likely to bias the identification of environmental microbes toward "pathogens". To overcome these sequencing problems, studies that have examined potential pathogens on plastics have isolated and/or quantified fecal indicator organisms, ${ }^{41,59,65,82,84,86}$ performed qPCR or tested microbial isolates for antimicrobial resistance genes ${ }^{65,69,98}$ and searched plastic metagenomes for antimicrobial resistance genes, ${ }^{97}$ but only two studies specifically examined the abundance of virulence or virulence-associated genes ${ }^{65,86}$ (SI Table S1). Interestingly, while Silva et al. (2019) ${ }^{86}$ found both Vibrio spp. and Escherichia coli virulence genes in isolates from plastics as well as the surrounding water, they find on average 11 virulence genes in isolates from water samples but only four in isolates from plastic samples. Similarly, Kirstein et al. (2016) ${ }^{65}$ found that only one $V$. parahaemolyticus isolate from their seawater sample, and none from the plastic, contained virulence-associated genes.

Do Pathogens Accumulate on Plastics and Are There Plastic-Specific Pathogens? In order to answer this question with currently available information, we must examine the studies that both look for potential pathogens and include a control substrate; Oberbeckmann et al. (2018) $)^{41}$ and Quilliam et al. (2014) ${ }^{82}$ (Figure 1). While, as mentioned above, evidence confirming pathogenicity is lacking, if we assume that those organisms are indeed pathogenic (i.e., fecal indicator organisms such as Vibrionales and Enterobacteriales) and take the results of these two studies ${ }^{41,82}$ with those that use a control substrate and use molecular methods, ${ }^{37,38,54,64,76-78,80,92,132,39-45,51}$ we must conclude that pathogens do not accumulate on plastics alone and nor are there plastic-specific pathogens. The majority of the studies that use a control substrate did not find them to be significantly associated with either plastics or control substrates. ${ }^{37,38,92,132,40,44,45,51,54,76,78,80}$ Interestingly, while Oberbeckmann et al. $(2018)^{41}$ found potential pathogens to be higher in abundance on control substrates than plastics, in another study (Oberbeckmann et al., 2016 ${ }^{77}$ ) they found Vibrio spp. to be (although not statistically significantly) higher in abundance on plastics than control substrates. On the other hand, both Frere et al. $(2018)^{59}$ and Quilliam et al. $(2014)^{82}$ found higher abundances of Vibrio spp. on plastics than in surrounding seawater or on seaweeds, respectively. Nevertheless, Quilliam et al. (2014) also found higher relative abundances of E. coli on seaweeds than plastics and that E. coli had enhanced survivability on seaweeds than on plastics. When brought together, this information highlights the stochasticity of microbial colonization of surfaces, especially when these surfaces are inert and do not have a positive selective pressure on particular microbial groups.

Do Plastics Act As Vectors for Pathogen Dispersal? In answering this question, we cannot ignore that plastics have increased residence times, buoyancy, and therefore transportability than other control substrates (i.e., wood or shells), as discussed above. However, the evidence presented in this section is not sufficient to answer the original question - "can plastics be claimed as specific vectors of pathogen dispersal?". Therefore, a correct assessment of the presence of real virulent pathogens and the evaluation of their persistence over space and time (e.g., from wastewater treatment plants to open oceans), as well as their presence on inert substrate controls is needed in order to determine the real risk plastics pose to marine life and human health. ${ }^{65}$ Furthermore, an area of research that is currently gaining interest and that would provide a definitive answer to this question is the 


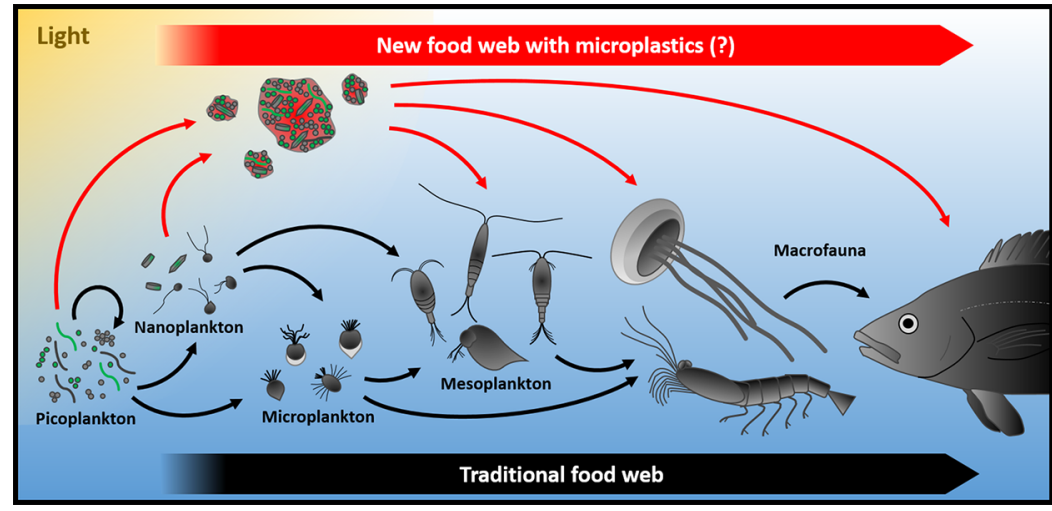

Figure 7. Hypothetical marine food web with the introduction of biofouled microplastics (in red).

epidemiological tracking of pathogen transfer from plastics to fauna under natural conditions.

\section{INFLUENCE OF THE PLASTISPHERE ON MARINE FOOD WEBS}

The effects of the Plastisphere on the wider ecological context of microplastics in the environment have been largely overlooked. It is important to consider that any interaction that plastic particles have with their surrounding environment is mediated through the ecocorona and the microbial biofilm that covers them. Therefore, we should examine microplasticbiofilm-environment interactions more closely, rather than simply microplastic-environment interactions. This avenue has already led to some surprising discoveries; one such aspect involves "flavoring". A study revealed that plastics which were exposed to seawater for 3 weeks acquired a dimethyl sulfide (DMS) signature, ${ }^{179}$ a chemical known to be exploited by foraging animals to identify potential feeding patches. ${ }^{180,181}$ Interestingly, the incidence of plastic ingestion was higher in DMS sensitive birds (48\%), compared with non-DMS responders (7.5\%; Savoca et al. 2016 ${ }^{179}$ ). Microplastics "flavored" in natural seawater have also been shown to induce foraging behavior in anchovies ${ }^{182}$ or increase ingestion rates in copepods. ${ }^{183}$ A curious exception was described by Allen, Seymour, and Rittschof (2017), ${ }^{184}$ who demonstrated that a coral (chemoreceptive feeder) consistently preferred pristine plastic pellets over biofouled ones.

Beyond emitting chemical cues, marine plastic debris could also provide a source of food as microbial biofilms are able to accumulate considerable amounts of organic nutrients (Figure 2). Numerous laboratory studies have investigated the effects of pristine noncolonized microplastic ingestion on the fitness of various organisms, e.g., ref 185 mainly observing a detrimental effect due to feeding of inert nondigestible particles. Considering that in nature microplastics are not only biofouled, but may even constitute "hot spots" of primary production in oligotrophic environments, ${ }^{48}$ feeding on such particles may lead to different results. We therefore recommend the implementation of biofouled particles (at environmentally relevant concentrations, if possible) as part of future feeding experiments or any other experimental setup.

Clearly, one of the most fascinating consequences of buoyant marine plastic debris is the appearance of a completely new niche within marine ecosystems, where microbial primary producers known to be pioneers in plastic colonization, i.e., cyanobacteria, ${ }^{48}$ diatoms, ${ }^{2}$ and algae, ${ }^{68}$ can grow on a surface that remains at the forefront of the sunlit ocean and live in meso- or even eutrophic conditions due to the buildup of nutrients within the biofilm, despite being in an ultraoligotrophic environment. This new niche may have profound and unexplored consequences in marine food webs as the web can now be "bypassed" when larger organisms feed directly on these microbial aggregations on plastics (Figure 7).

\section{CONCLUDING REMARKS}

Research has so far demonstrated that Plastisphere communities do not starkly differ from microbial assemblies that form on other similarly inert surfaces, mainly because secondary biofilms that are formed in mature assemblages may not even "see" the material's surface. This review picks up on the tremendous increase in knowledge this field has experienced in recent years, but identifies gaps and challenging issues that will require further thought and elaborate experimentation:

- A thorough physical characterization of Plastisphere biofilms (i.e., biofilm thickness, biomass and density), yielding crucial parameters to model the influence biofilms may have on microplastic behavior;

- Inclusion of relevant controls for biofilm specificity studies (e.g., glass, wood or ceramics) in order to have a reliable indication of whether plastic surfaces really enrich for particular communities or processes;

- Evaluation of different successional stages during biofilm formation, particularly at very early temporal stages;

- Assess the differences-physical and taxonomicbetween Plastispheres at different depths, as well as the impact when the plastics oscillate in the water column;

- Stronger consideration of biofouled microplastics for experiments, particularly in ecotoxicology and ingestion studies, to better approximate to natural conditions;

- Use of environmentally relevant concentrations of both nutrients and materials to correctly assess the real risk these materials pose in the natural environment;

- Start prioritizing and identifying mechanisms, and avoid relying on taxonomy, to assess functional processes that occur, or that are contained, within the Plastisphere such as biodegradation or pathogenicity.

This last point may be the most tenacious challenge to be tackled in future research. Determining community composition and taxonomy may no longer be enough to justify claims about the presence of biodegraders or pathogens in the Plastisphere. Future work will require going "back to the bench" and identifying the mechanisms involved in degrada- 
tion processes to correctly interpret what is happening in nature.

While we may all agree on the negative impact that plastics have on the environment-mainly because these synthetic materials are out of place and, as such, are pollutants-we must also try to use conditions as close to nature as possible and collect robust information to support our claims. While some speculation is acceptable, overstatements must be avoided. Using unrealistic concentrations to prove that plastics produce negative effects, or not reporting that control materials present similar effects to those observed for plastics, should not be encouraged to avoid misleading messages and further vilifying of plastics, which have provided innumerable societal benefits and, in many cases, have a smaller carbon footprint than alternative materials.

\section{ASSOCIATED CONTENT}

\section{SI Supporting Information}

The Supporting Information is available free of charge at https://pubs.acs.org/doi/10.1021/acs.est.0c02305.

Table S1 summarizes the studies identified by a Web of Science literature search using the keywords "Plastics Plastisphere", "Plastics microbial community", and "Plastics microbial degradation" that report on colonization or degradation of nonbiodegradable plastics in the marine environment (PDF)

\section{AUTHOR INFORMATION}

\section{Corresponding Author}

Joseph A. Christie-Oleza - University of the Balearic Islands, Palma 07122, Spain; IMEDEA (CSIC-UIB), Esporles 07190,

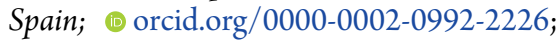

Email: joseph.christie@uib.eu

\section{Authors}

Robyn J. Wright - Department of Pharmacology, Faculty of Medicine, Dalhousie University, Halifax, Nova Scotia B3H

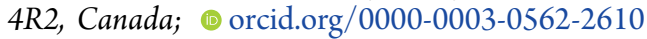

Gabriel Erni-Cassola - Man-Society-Environment (MSE) program, University of Basel, Basel 4003, Switzerland; 으 orcid.org/0000-0002-9056-0188

Vinko Zadjelovic - School of Life Sciences, University of Warwick, Coventry CV4 7AL, U.K.

Mira Latva - School of Life Sciences and Department of Physics, University of Warwick, Coventry CV4 7AL, U.K.; 이이.org/ 0000-0002-9551-9336

Complete contact information is available at: https://pubs.acs.org/10.1021/acs.est.0c02305

\section{Author Contributions}

$\nabla$ These authors contributed equally to the work.

\section{Author Contributions}

R.J.W., G.E.C., and J.C.O. conceived the initial idea for the review and wrote the first draft. All authors had a strong intellectual input and contributed significantly with revisions.

\section{Notes}

The authors declare no competing financial interest.

\section{ACKNOWLEDGMENTS}

R.J.W. was supported by an MIBTP PhD scholarship (BB/ $\mathrm{M} 01116 \mathrm{X} / 1$ ) and Waitrose \& Partners as part of the Association of Commonwealth Universities Blue Charter
Programme. G.E.-C. was supported by a NERC CENTA $\mathrm{PhD}$ scholarship. V.Z. was supported by CONICYT-BECAS CHILE/Doctorado Becas Chile en el Extranjero, Folio 72160583 and NERC research project NE/S005501/1. M.L. was supported by an MIBTP PhD scholarship (BB/M01116X/ 1). J.C.-O. was supported by the NERC Independent Research Fellowship NE/K009044/1, Ramón y Cajal contract RYC2017-22452 (funded by the Ministry of Science, Innovation and Universities, the National Agency of Research, and the European Social Fund) and MINECO project PID2019109509RB-I00 (FEDER cofunding). We thank Dr Ferran Hierro and Dr Rafael Bosch for image acquisition.

\section{REFERENCES}

(1) Geyer, R.; Jambeck, J. R.; Law, K. L. Production, Use, and Fate of All Plastics Ever Made. Sci. Adv. 2017, 3, e1700782.

(2) Jambeck, J.; Geyer, R.; Wilcox, C.; Siegler, T.; Perryman, M.; Andrady, A.; Narayan, R.; Law, K. Plastic Waste Inputs from Land into the Ocean. Science (Washington, DC, U. S.) 2015, 347 (6223), 768-771.

(3) Allen, S.; Allen, D.; Phoenix, V. R.; Le Roux, G.; Durántez Jiménez, P.; Simonneau, A.; Binet, S.; Galop, D. Atmospheric Transport and Deposition of Microplastics in a Remote Mountain Catchment. Nat. Geosci. 2019, 12 (5), 339-344.

(4) Van Sebille, E.; Wilcox, C.; Sherman, P.; Hardesty, B. D.; Law, K. L. Modelling Global Distribution, Risk and Mitigation Strategies of Floating Plastic Pollution. In Geophysical Research Abstracts EGU General Assembly, 2016; Vol. 18.

(5) Cózar, A.; Echevarría, F.; González-Gordillo, J. I.; Irigoien, X.; Ubeda, B.; Hernández-Léon, S.; Palma, Á. T.; Navarro, S.; García-deLomas, J.; Ruiz, A.; Fernández-de-Puelles, M. L.; Duarte, C. M. Plastic Debris in the Open Ocean. Proc. Natl. Acad. Sci. U. S. A. 2014, 111 (28), 10239-10244.

(6) Bergmann, M.; Wirzberger, V.; Krumpen, T.; Lorenz, C.; Primpke, S.; Tekman, M. B.; Gerdts, G. High Quantities of Microplastic in Arctic Deep-Sea Sediments from the HAUSGARTEN Observatory. Environ. Sci. Technol. 2017, 51, 11000-11010.

(7) Lavers, J. L.; Bond, A. L. Exceptional and Rapid Accumulation of Anthropogenic Debris on One of the World's Most Remote and Pristine Islands. Proc. Natl. Acad. Sci. U. S. A. 2017, 114, 201619818.

(8) Reed, S.; Clark, M.; Thompson, R.; Hughes, K. A. Microplastics in Marine Sediments near Rothera Research Station. Mar. Pollut. Bull. 2018, 133, 460-463.

(9) Thiel, M.; Gutow, L. The Ecology of Rafting in the Marine Environment. II. The Rafting Organisms and Community. Oceanogr. Mar. Biol. 2005, 43 (1), 279-418.

(10) Bixler, G. D.; Bhushan, B. Review Article: Biofouling: Lessons from Nature. Philos. Trans. R. Soc., A 2012, 370 (1967), 2381-2417.

(11) Carpenter, E. J.; Smith, K. L. J. Plastics on the Sargasso Sea Surface. Science (Washington, DC, U. S.) 1972, 175 (4027), 12401241.

(12) Zettler, E. R.; Mincer, T. J.; Amaral-Zettler, L. A. Life in the "Plastisphere": Microbial Communities on Plastic Marine Debris. Environ. Sci. Technol. 2013, 47 (13), 7137-7146.

(13) McCormick, A.; Hoellein, T. J.; Mason, S. A.; Schluep, J.; Kelly, J. J. Microplastic Is an Abundant and Distinct Microbial Habitat in an Urban River. Environ. Sci. Technol. 2014, 48, 11863-11871.

(14) Reisser, J.; Shaw, J.; Hallegraeff, G.; Proietti, M.; Barnes, D. K. A.; Thums, M.; Wilcox, C.; Hardesty, B. D.; Pattiaratchi, C. Millimeter-Sized Marine Plastics: A New Pelagic Habitat for Microorganisms and Invertebrates. PLoS One 2014, 9 (6), 1-11.

(15) De Tender, C.; Devriese, L. I.; Haegeman, A.; Maes, S.; Vangeyte, J.; Cattrijsse, A.; Dawyndt, P.; Ruttink, T. Temporal Dynamics of Bacterial and Fungal Colonization on Plastic Debris in the North Sea. Environ. Sci. Technol. 2017, 51 (13), 7350-7360.

(16) Gregory, M. R. Environmental Implications of Plastic Debris in Marine Settings-Entanglement, Ingestion, Smothering, Hangers-on, 
Hitch-Hiking and Alien Invasions. Philos. Trans. R. Soc., B 2009, 364 (1526), 2013-2025.

(17) Hartmann, N.; Hüffer, T.; Thompson, R. C.; Hassellöv, M.; Verschoor, A.; Daugaard, A. E.; Rist, S.; Karlsson, T. M.; Brennholt, N.; Cole, M.; Herrling, M. P.; Heß, M.; Ivleva, N. P.; Lusher, A. L.; Wagner, M. Are We Speaking the Same Language? Recommendations for a Definition and Categorization Framework for Plastic Debris. Environ. Sci. Technol. 2019, 53 (3), 1039-1047.

(18) Jacquin, J.; Cheng, J.; Odobel, C.; Pandin, C.; Conan, P.; PujoPay, M.; Barbe, V.; Meistertzheim, A.-L.; Ghiglione, J.-F. Microbial Ecotoxicology of Marine Plastic Debris: A Review on Colonization and Biodegradation by the "Plastisphere. Front. Microbiol. 2019, 10 (April), 1-16.

(19) Roager, L.; Sonnenschein, E. C. Bacterial Candidates for Colonization and Degradation of Marine Plastic Debris. Environ. Sci. Technol. 2019, 53 (20), 11636-11643.

(20) Amaral-Zettler, L. A.; Zettler, E. R.; Mincer, T. J. Ecology of the Plastisphere. Nat. Rev. Microbiol. 2020, 18, 139-151.

(21) Oberbeckmann, S.; Labrenz, M. Marine Microbial Assemblages on Microplastics: Diversity, Adaptation, and Role in Degradation. Annu. Rev. Mar. Sci. 2020, 12, 1-24.

(22) Rogers, K. L.; Carreres-calabuig, J. A.; Gorokhova, E.; Posth, N. R. Micro-by-Micro Interactions: How Microorganisms Influence the Fate of Marine Microplastics. Limnol. Oceanogr. Lett. 2020, 5, 1-19.

(23) Xu, D.; Jia, R.; Li, Y.; Gu, T. Advances in the Treatment of Problematic Industrial Biofilms. World J. Microbiol. Biotechnol. 2017, 33 (97), 1-10.

(24) Costerton, J. W.; Lewandowski, Z.; Caldwell, D. E.; Korber, D. R.; Lappin-Scott, H. M. Microbial Biofilms. Annu. Rev. Microbiol. 1995, 49, 711-745.

(25) Hall-Stoodley, L.; Costerton, J. W.; Stoodley, P.; State, M. Engineering, B. Bacterial Biofilms: From the Natural Environment to Infectious Diseases. Nat. Rev. Microbiol. 2004, 2 (2), 95-108.

(26) Flemming, H.-C.; Wingender, J.; Szewzyk, U.; Steinberg, P.; Rice, S. A. Kjelleberg, S. Biofilms: An Emergent Form of Bacterial Life. Nat. Rev. Microbiol. 2016, 14 (9), 563-575.

(27) Hall, C. W.; Mah, T. F. Molecular Mechanisms of BiofilmBased Antibiotic Resistance and Tolerance in Pathogenic Bacteria. FEMS Microbiol. Rev. 2017, 41 (3), 276-301.

(28) Gloor, G. B.; Macklaim, J. M.; Pawlowsky-Glahn, V.; Egozcue, J. J. Microbiome Datasets Are Compositional: And This Is Not Optional. Front. Microbiol. 2017, 8 (NOV), 1-6.

(29) Azeredo, J.; Azevedo, N. F.; Briandet, R.; Cerca, N.; Coenye, T.; Costa, A. R.; Desvaux, M.; Di Bonaventura, G.; Hébraud, M.; Jaglic, Z.; Kačániová, M.; Knøchel, S.; Lourenço, A.; Mergulhão, F.; Meyer, R. L.; Nychas, G.; Simões, M.; Tresse, O.; Sternberg, C. Critical Review on Biofilm Methods. Crit. Rev. Microbiol. 2017, 43 (3), 315-351.

(30) Datta, M. S.; Sliwerska, E.; Gore, J.; Polz, M. F.; Cordero, O. X. Microbial Interactions Lead to Rapid Micro-Scale Successions on Model Marine Particles. Nat. Commun. 2016, 7 (11965), 1-7.

(31) Wright, R. J.; Gibson, M. I.; Christie-Oleza, J. A. Understanding Microbial Community Dynamics to Improve Optimal Microbiome Selection. Microbiome 2019, 7 (85), 1-14.

(32) Whitchurch, C. B.; Tolker-Nielsen, T.; Ragas, P. C.; Mattick, J. S. Extracellular DNA Required for Bacterial Biofilm Formation. Science (Washington, DC, U. S.) 2002, 295 (5559), 1487.

(33) Kembel, S. W.; Wu, M.; Eisen, J. A.; Green, J. L. Incorporating $16 \mathrm{~S}$ Gene Copy Number Information Improves Estimates of Microbial Diversity and Abundance. PLoS Comput. Biol. 2012, 8 (10), 16-18.

(34) Louca, S.; Doebeli, M.; Parfrey, L. W. Correcting for $16 \mathrm{~S}$ RRNA Gene Copy Numbers in Microbiome Surveys Remains an Unsolved Problem. Microbiome 2018, 6 (1), 1-12.

(35) Schlundt, C.; Welch, J. L. M.; Knochel, A. M.; Zettler, E. R.; Amaral-Zettler, L. A. Spatial Structure in the "Plastisphere": Molecular Resources for Imaging Microscopic Communities on Plastic Marine Debris. Mol. Ecol. Resour. 2020, 20 (November), 1-15.
(36) Dang, H.; Lovell, C. R. Microbial Surface Colonization and Biofilm Development in Marine Environments. Microbiol. Mol. Biol. Rev. 2016, 80 (1), 91-138.

(37) Erni-Cassola, G.; Wright, R. J.; Gibson, M. I.; Christie-Oleza, J. A. Early Colonization of Weathered Polyethylene by Distinct Bacteria in Marine Coastal Seawater. Microb. Ecol. 2020.79517

(38) Pinto, M.; Langer, T. M.; Huffer, T.; Hofmann, T.; Herndl, G. J.; Hüffer, T.; Hofmann, T.; Herndl, G. J. The Composition of Bacterial Communities Associated with Plastic Biofilms Differs between Different Polymers and Stages of Biofilm Succession. PLoS One 2019, 14 (6), 1-20.

(39) Kettner, M. T.; Rojas-Jimenez, K.; Oberbeckmann, S.; Labrenz, M.; Grossart, H.-P. Microplastics Alter Composition of Fungal Communities in Aquatic Ecosystems. Environ. Microbiol. 2017, 19, 4447-4459.

(40) Muthukrishnan, T.; Khaburi, M.; Abed, R. M. M. Fouling Microbial Communities on Plastics Compared with Wood and Steel: Are They Substrate- or Location-Specific? Microb. Ecol. 2019.78361

(41) Oberbeckmann, S.; Kreikemeyer, B.; Labrenz, M. Environmental Factors Support the Formation of Specific Bacterial Assemblages on Microplastics. Front. Microbiol. 2018, 8, 1-12.

(42) Kettner, M. T.; Oberbeckmann, S.; Labrenz, M.; Grossart, H. P. The Eukaryotic Life on Microplastics in Brackish Ecosystems. Front. Microbiol. 2019, 10, 538.

(43) Kesy, K.; Oberbeckmann, S.; Kreikemeyer, B.; Labrenz, M. Spatial Environmental Heterogeneity Determines Young Biofilm Assemblages on Microplastics in Baltic Sea Mesocosms. Front. Microbiol. 2019, 10 (August), 1-18.

(44) Kirstein, I. V.; Wichels, A.; Krohne, G.; Gerdts, G. Mature Biofilm Communities on Synthetic Polymers in Seawater - Specific or General? Mar. Environ. Res. 2018, 142, 147-154.

(45) Kirstein, I. V.; Wichels, A.; Gullans, E.; Krohne, G.; Gerdts, G. The Plastisphere - Uncovering Tightly Attached Plastic "Specific" Microorganisms. PLoS One 2019, 14 (4), 1-17.

(46) Amaral-Zettler, L. A.; Zettler, E. R.; Slikas, B.; Boyd, G. D.; Melvin, D. W.; Morrall, C. E.; Proskurowski, G.; Mincer, T. J. The Biogeography of the Plastisphere: Implications for Policy. Front. Ecol. Environ. 2015, 13 (10), 541-546.

(47) Baptista Neto, J. A.; Gaylarde, C.; Beech, I.; Bastos, A. C.; Quaresma, V. da S.; de Carvalho, D. G.; Baptista Neto, J. A.; Gaylarde, C.; Beech, I.; Bastos, A. C.; da Silva Quaresma, V.; de Carvalho, D. G. Microplastics and Attached Microorganisms in Sediments of the Vitória Bay Estuarine System in SE Brazil. Ocean Coast. Manag. 2019, 169 (September 2018), 247-253.

(48) Bryant, J. A.; Clemente, T. M.; Viviani, D. A.; Fong, A. A.; Thomas, K. A.; Kemp, P.; Karl, D. M.; White, A. E.; DeLong, E. F. Diversity and Activity of Communities Inhabiting Plastic Debris in the North Pacific Gyre. mSystems 2016, 1 (3), e00024-16.

(49) Carson, H. S.; Nerheim, M. S.; Carroll, K. A.; Eriksen, M. The Plastic-Associated Microorganisms of the North Pacific Gyre. Mar. Pollut. Bull. 2013, 75, 126-132.

(50) Curren, E.; Leong, S. C. Y. Profiles of Bacterial Assemblages from Microplastics of Tropical Coastal Environments. Sci. Total Environ. 2019, 655, 313-320.

(51) Dang, H.; Li, T.; Chen, M.; Huang, G. Cross-Ocean Distribution of Rhodobacterales Bacteria as Primary Surface Colonizers in Temperate Coastal Marine Waters. Appl. Environ. Microbiol. 2008, 74 (1), 52-60.

(52) De Tender, C. A.; Devriese, L. I.; Haegeman, A.; Maes, S.; Ruttink, T.; Dawyndt, P. Bacterial Community Profiling of Plastic Litter in the Belgian Part of the North Sea. Environ. Sci. Technol. 2015, 49, 9629-9638.

(53) De Tender, C. A.; Devriese, L. I.; Haegeman, A.; Maes, S.; Vangeyte, J.; Cattrijsse, A.; Dawyndt, P.; Ruttink, T. The Temporal Dynamics of Bacterial and Fungal Colonization on Plastic Debris in the North Sea. Environ. Sci. Technol. 2017, 51 (13), 7350-7360.

(54) Didier, D.; Anne, M.; Alexandra, T. H. Plastics in the North Atlantic Garbage Patch: A Boat-Microbe for Hitchhikers and Plastic Degraders. Sci. Total Environ. 2017, 599-600, 1222-1232. 
(55) Delacuvellerie, A.; Cyriaque, V.; Gobert, S.; Benali, S.; Wattiez, R. The Plastisphere in Marine Ecosystem Hosts Potential Specific Microbial Degraders Including Alcanivorax Borkumensis as a Key Player for the Low-Density Polyethylene Degradation. J. Hazard. Mater. 2019, 380 (July), 120899.

(56) Devi, R. S.; Ramya, R.; Kannan, K.; Antony, A. R.; Kannan, V. $\mathrm{R}$. Investigation of Biodegradation Potentials of High Density Polyethylene Degrading Marine Bacteria Isolated from the Coastal Regions of Tamil Nadu. Mar. Pollut. Bull. 2019, 138, 549-560.

(57) Dussud, C.; Hudec, C.; George, M.; Fabre, P.; Higgs, P.; Bruzaud, S.; Delort, A.; Eyheraguibel, B.; Meistertzheim, A.; Jacquin, J.; Cheng, J.; Callac, N. Colonization of Non-Biodegradable and Biodegradable Plastics by Marine Microorganisms. Front. Microbiol. 2018, 9, 1-13.

(58) Dussud, C.; Meistertzheim, A. L.; Conan, P.; Pujo-pay, M.; George, M.; Fabre, P.; Coudane, J.; Higgs, P.; Elineau, A.; Pedrotti, M. L.; Gorsky, G.; Ghiglione, J. F. Evidence of Niche Partitioning among Bacteria Living on Plastics, Organic Particles and Surrounding Seawaters. Environ. Pollut. 2018, 236, 807-816.

(59) Frère, L.; Maignien, L.; Chalopin, M.; Huvet, A.; Rinnert, E.; Morrison, H.; Kerninon, S.; Cassone, A.-L. L.; Lambert, C.; Reveillaud, J.; Paul-Pont, I.; Frere, L.; Maignien, L.; Chalopin, M.; Huvet, A.; Rinnert, E.; Morrison, H.; Kerninon, S.; Cassone, A.-L. L.; Lambert, C.; Reveillaud, J.; Paul-Pont, I. Microplastic Bacterial Communities in the Bay of Brest: Influence of Polymer Type and Size. Environ. Pollut. 2018, 242, 614-625.

(60) Harrison, J. P.; Schratzberger, M.; Sapp, M.; Osborn, A. M. Rapid Bacterial Colonization of Low-Density Polyethylene Microplastics in Coastal Sediment Microcosms. BMC Microbiol. 2014, 14 (232), $1-15$.

(61) Harshvardhan, K.; Jha, B. Biodegradation of Low-Density Polyethylene by Marine Bacteria from Pelagic Waters, Arabian Sea, India. Mar. Pollut. Bull. 2013, 77 (1-2), 100-106.

(62) Jiang, P.; Zhao, S.; Zhu, L.; Li, D. Microplastic-Associated Bacterial Assemblages in the Intertidal Zone of the Yangtze Estuary. Sci. Total Environ. 2018, 624, 48-54.

(63) Kathiresan, K. Polythene and Plastics-Degrading Microbes from the Mangrove Soil. Rev. Biol. Trop. 2003, 51 (3), 629-634.

(64) Kesy, K.; Oberbeckmann, S.; Müller, F.; Labrenz, M. Polystyrene Influences Bacterial Assemblages in Arenicola MarinaPopulated Aquatic Environments in Vitro. Environ. Pollut. 2016, 219, 219-227.

(65) Kirstein, I. V.; Kirmizi, S.; Wichels, A.; Garin-Fernandez, A.; Erler, R.; Löder, M.; Gerdts, G. Dangerous Hitchhikers? Evidence for Potentially Pathogenic Vibrio Spp. on Microplastic Particles. Mar. Environ. Res. 2016, 120, 1-8.

(66) Kumar, S.; Hatha, A. A. M.; Christi, K. S. Diversity and Effectiveness of Tropical Mangrove Soil Microflora on the Degradation of Polythene Carry Bags. Rev. Biol. Trop. 2007, 55, 777-786.

(67) Kumar, M.; Xie, A.; Curley, J. Determining the Potential Secondary Impacts Associated with Microorganismal Biodegradation of Microplastics in the Marine Environment. J. Exp. Second. Sci. 2016, 3 (4), 1-11.

(68) Lacerda, A. L. F.; Rodrigues, L. S.; Van Sebille, E.; Rodrigues, F. L.; Ribeiro, L.; Secchi, E. R.; Kessler, F.; Proietti, M. C. Plastics in Sea Surface Waters around the Antarctic Peninsula. Sci. Rep. 2019, 9 (3977), $1-12$.

(69) Laganà, P.; Caruso, G.; Corsi, I.; Bergami, E.; Venuti, V.; Majolino, D.; La, R.; Azzaro, M.; Cappello, S. Do Plastics Serve as a Possible Vector for the Spread of Antibiotic Resistance? First Insights from Bacteria Associated to a Polystyrene Piece from King George Island (Antarctica). Int. J. Hyg. Environ. Health 2019, 222 (1), 89100.

(70) Lobelle, D.; Cunliffe, M. Early Microbial Biofilm Formation on Marine Plastic Debris. Mar. Pollut. Bull. 2011, 62 (1), 197-200.

(71) Masó, M.; Garcés, E.; Pagès, F.; Camp, J. Drifting Plastic Debris as a Potential Vector for Dispersing Harmful Algal Bloom (HAB) Species. Sci. Mar. 2003, 67 (1), 107-111.
(72) Michels, J.; Stippkugel, A.; Lenz, M.; Wirtz, K.; Engel, A. Rapid Aggregation of Biofilm-Covered Microplastics with Marine Biogenic Particles. Proc. R. Soc. London, Ser. B 2018, 285 (1885). https:// doi.org/10.1098/rspb.2018.1203.20181203

(73) Misic, C.; Covazzi Harriague, A. Development of Marine Biofilm on Plastic: Ecological Features in Different Seasons, Temperatures, and Light Regimes. Hydrobiologia 2019, 835 (1), 129-145.

(74) Mohanrasu, K.; Premnath, N.; Prakash, G. S.; Sudhakar, M.; Boobalan, T. Exploring Multi Potential Uses of Marine Bacteria; an Intgrated Approach for PHB Production, PAHs and Polyethylene Biodegradation. J. Photochem. Photobiol., B 2018, 185 (May), 55-65.

(75) Nauendorf, A.; Krause, S.; Bigalke, N. K.; Gorb, E. V.; Gorb, S. N.; Haeckel, M.; Wahl, M.; Treude, T. Microbial Colonization and Degradation of Polyethylene and Biodegradable Plastic Bags in Temperate Fine-Grained Organic-Rich Marine Sediments. Mar. Pollut. Bull. 2016, 103 (1-2), 168-178.

(76) Oberbeckmann, S.; Loeder, M. G. J.; Gerdts, G.; Osborn, A. M. Spatial and Seasonal Variation in Diversity and Structure of Microbial Biofilms on Marine Plastics in Northern European Waters. FEMS Microbiol. Ecol. 2014, 90, 478-492.

(77) Oberbeckmann, S.; Osborn, A. M.; Duhaime, M. B. Microbes on a Bottle: Substrate, Season and Geography Influence Community Composition of Microbes Colonizing Marine Plastic Debris. PLoS One 2016, 11 (8), 1-24.

(78) Ogonowski, M.; Motiei, A.; Ininbergs, K.; Hell, E.; Gerdes, Z.; Udekwu, K. I.; Bacsik, Z.; Gorokhova, E. Evidence for Selective Bacterial Community Structuring on Microplastics. Environ. Microbiol. 2018, 20 (8), 2796-2808.

(79) Paço, A.; Duarte, K.; da Costa, J. P.; Santos, P. S. M.; Pereira, R.; Pereira, M. E.; Freitas, A. C.; Duarte, A. C.; Rocha-Santos, T. A. P. Biodegradation of Polyethylene Microplastics by the Marine Fungus Zalerion Maritimum. Sci. Total Environ. 2017, 586, 10-15.

(80) Pinnell, L. J.; Turner, J. W. Shotgun Metagenomics Reveals the Benthic Microbial Community Response to Plastic and Bioplastic in a Coastal Marine Environment. Front. Microbiol. 2019, 10 (1252), 113.

(81) Pollet, T.; Berdjeb, L.; Garnier, C. C.; Durrieu, G. G.; Le Poupon, C.; Misson, B.; Jean-François, B.; Briand, J.-F. Prokaryotic Community Successions and Interactions in Marine Biofilms: The Key Role of Flavobacteriia. FEMS Microb. Ecol. 2018, 94 (6), 1-13.

(82) Quilliam, R. S.; Jamieson, J.; Oliver, D. M. Seaweeds and Plastic Debris Can Influence the Survival of Faecal Indicator Organisms in Beach Environments. Mar. Pollut. Bull. 2014, 84 (1-2), 201-207.

(83) Raghul, S. S.; Bhat, S. G.; Chandrasekaran, M.; Francis, V.; Thachil, E. T. Biodegradation of Polyvinyl Alcohol-Low Linear Density Polyethylene-Blended Plastic Film by Consortium of Marine Benthic Vibrios. Int. J. Environ. Sci. Technol. 2014, 11, 1827-1834.

(84) Rodrigues, A.; Oliver, D. M.; Mccarron, A.; Quilliam, R. S. Colonisation of Plastic Pellets (Nurdles) by E. Coli at Public Bathing Beaches. Mar. Pollut. Bull. 2019, 139, 376-380.

(85) Romera-Castillo, C.; Pinto, M.; Langer, T. M.; Álvarez-Salgado, X. A.; Herndl, G. J. Dissolved Organic Carbon Leaching from Plastics Stimulates Microbial Activity in the Ocean. Nat. Commun. 2018, 9 (1), 1-7.

(86) Silva, M. M.; Maldonado, G. C.; Castro, R. O.; de Sá Felizardo, J.; Cardoso, R. P.; dos Anjos, R. M.; de. Araújo, F. V. Dispersal of Potentially Pathogenic Bacteria by Plastic Debris in Guanabara Bay, RJ, Brazil. Mar. Pollut. Bull. 2019, 141 (March), 561-568.

(87) Sudhakar, M.; Doble, M.; Murthy, P. S.; Venkatesan, R. Marine Microbe-Mediated Biodegradation of Low- and High-Density Polyethylenes. Int. Biodeterior. Biodegrad. 2008, 61 (3), 203-213.

(88) Summers, S.; Henry, T.; Gutierrez, T. Agglomeration of Nanoand Microplastic Particles in Seawater by Autochthonous and de Novo-Produced Sources of Exopolymeric Substances. Mar. Pollut. Bull. 2018, 130 (March), 258-267.

(89) Syranidou, E.; Karkanorachaki, K.; Amorotti, F.; Franchini, M.; Repouskou, E.; Kaliva, M.; Vamvakaki, M.; Kolvenbach, B.; Fava, F.; Corvini, P. F. X.; Kalogerakis, N. Biodegradation of Weathered 
Polystyrene Films in Seawater Microcosms. Sci. Rep. 2017, 7 (1), 112.

(90) Syranidou, E.; Karkanorachaki, K.; Amorotti, F.; Repouskou, E.; Kroll, K.; Kolvenbach, B.; Corvini, P. F.; Fava, F.; Kalogerakis, N. Development of Tailored Indigenous Marine Consortia for the Degradation of Naturally Weathered Polyethylene Films. PLoS One 2017, 12 (8), 1-21.

(91) Syranidou, E.; Karkanorachaki, K.; Amorotti, F.; Avgeropoulos, A.; Kolvenbach, B.; Zhou, N.; Fava, F.; Corvini, P. F.; Kalogerakis, N. Biodegradation of Mixture of Plastic Films by Tailored Marine Consortia. J. Hazard. Mater. 2019, 375, 33-42.

(92) Tagg, A. S.; Oberbeckmann, S.; Fischer, D.; Kreikemeyer, B.; Labrenz, M. Paint Particles Are a Distinct and Variable Substrate for Marine Bacteria. Mar. Pollut. Bull. 2019, 146 (June), 117-124.

(93) Tsiota, P.; Karkanorachaki, K.; Syranidou, E.; Franchini, M.; Kalogerakis, N. Microbial Degradation of HDPE Secondary Microplastics: Preliminary Results. In Proceedings of the International Conference on Microplastic Pollution in the Mediterranean Sea, 2018; pp 181-188. DOI: $10.1007 / 978-3-319-71279-6$.

(94) Webb, H. K.; Crawford, R. J.; Sawabe, T.; Ivanova, E. P. Poly(Ethylene Terephthalate) Polymer Surfaces as a Substrate for Bacterial Attachment and Biofilm Formation. Microbes Environ. 2009, 24 (1), 39-42.

(95) Wu, N.; Zhang, Y.; Zhao, Z.; He, J.; Li, W.; Li, J.; Xu, W.; Ma, Y.; Niu, Z. Colonization Characteristics of Bacterial Communities on Microplastics Compared with Ambient Environments (Water and Sediment) in Haihe Estuary. Sci. Total Environ. 2020, xxxxx, 134876.

(96) Xu, X.; Wang, S.; Gao, F.; Li, J.; Zheng, L.; Sun, C.; He, C.; Wang, Z.; Qu, L. Marine Microplastic-Associated Bacterial Community Succession in Response to Geography, Exposure Time, and Plastic Type in China's Coastal Seawaters. Mar. Pollut. Bull. 2019, 145 (May), 278-286.

(97) Yang, Y.; Liu, G.; Song, W.; Ye, C.; Lin, H.; Li, Z.; Liu, W. Plastics in the Marine Environment Are Reservoirs for Antibiotic and Metal Resistance Genes. Environ. Int. 2019, 123 (1), 79-86.

(98) Zhang, Y.; Lu, J.; Wu, J.; Wang, J.; Luo, Y. Potential Risks of Microplastics Combined with Superbugs: Enrichment of Antibiotic Resistant Bacteria on the Surface of Microplastics in Mariculture System. Ecotoxicol. Environ. Saf. 2020, 187 (September 2019), 109852.

(99) Wei, R.; Zimmermann, W. Microbial Enzymes for the Recycling of Recalcitrant Petroleum-Based Plastics: How Far Are We? Microb. Biotechnol. 2017, 10 (6), 1308-1322.

(100) Simon, M.; Scheuner, C.; Meier-Kolthoff, J. P.; Brinkhoff, T.; Wagner-Döbler, I.; Ulbrich, M.; Klenk, H. P.; Schomburg, D.; Petersen, J.; Göker, M. Phylogenomics of Rhodobacteraceae Reveals Evolutionary Adaptation to Marine and Non-Marine Habitats. ISME J. 2017, 11 (6), 1483-1499.

(101) Kletou, D.; Hall-Spencer, J. M. Threats to Ultraoligotrophic Marine Ecosystems. In Marine Ecosystems; Cruzado, A., Ed.; InTech, 2012; pp 1-34. DOI: $10.5772 / 34842$.

(102) Dufresne, A.; Salanoubat, M.; Partensky, F.; Artiguenave, F.; Axmann, I. M.; Barbe, V.; Duprat, S.; Galperin, M. Y.; Koonin, E. V.; Le Gall, F.; Makarova, K. S.; Ostrowski, M.; Oztas, S.; Robert, C.; Rogozin, I. B.; Scanlan, D. J.; De Marsac, N. T.; Weissenbach, J.; Wincker, P.; Wolf, Y. I.; Hess, W. R. Genome Sequence of the Cyanobacterium Prochlorococcus Marinus SS120, a Nearly Minimal Oxyphototrophic Genome. Proc. Natl. Acad. Sci. U. S. A. 2003, 100 (17), 10020-10025.

(103) Giovannoni, S. J.; Tripp, H. J.; Givan, S.; Podar, M.; Vergin, K. L.; Baptista, D.; Bibbs, L.; Eads, J.; Richardson, T. H.; Noordewier, M.; Rappé, M. S.; Short, J. M.; Carrington, J. C.; Mathur, E. J. Genome Streamlining in a Cosmopolitan Oceanic Bacterium. Science (Washington, DC, U. S.) 2005, 309 (5738), 1242-1245.

(104) Van Mooy, B. A. S.; Rocap, G.; Fredricks, H. F.; Evans, C. T.; Devol, A. H. Sulfolipids Dramatically Decrease Phosphorus Demand by Picocyanobacteria in Oligotrophic Marine Environments. Proc. Natl. Acad. Sci. U. S. A. 2006, 103 (23), 8607-8612.
(105) Christie-Oleza, J. A.; Sousoni, D.; Lloyd, M.; Armengaud, J.; Scanlan, D. J. Nutrient Recycling Facilitates Long-Term Stability of Marine Microbial Phototroph-Heterotroph Interactions. Nat. Microbiol. 2017, 2, 1-10.

(106) Erni-Cassola, G.; Zadjelovic, V.; Gibson, M. I.; Christie-Oleza, J. A. Distribution of Plastic Polymer Types in the Marine Environment; A Meta-Analysis. J. Hazard. Mater. 2019, 369 (November 2018), 691-698.

(107) Kooi, M.; Van Nes, E. H.; Scheffer, M.; Koelmans, A. A. Ups and Downs in the Ocean: Effects of Biofouling on the Vertical Transport of Microplastics. Environ. Sci. Technol. 2017, 51 (14), 7963-7971.

(108) Dudek, K. L.; Cruz, B. N.; Polidoro, B.; Neuer, S. Microbial Colonization of Microplastics in the Caribbean Sea. Limnol. Oceanogr. Lett. 2020, 5, 5-17.

(109) Baas Becking, L. G. M. Geobiologie of Inleiding Tot de Milieukunde, 1934.

(110) De Wit, R.; Bouvier, T. Everything Is Everywhere, but, the Environment Selects"; What Did Baas Becking and Beijerinck Really Say? Environ. Microbiol. 2006, 8 (4), 755-758.

(111) Stocker, R.; Seymour, J. R.; Samadani, A.; Hunt, D. E.; Polz, M. F. Rapid Chemotactic Response Enables Marine Bacteria to Exploit Ephemeral Microscale Nutrient Patches. Proc. Natl. Acad. Sci. U. S. A. 2008, 105 (11), 4209-4214.

(112) Long, R. A.; Azam, F. Microscale Patchiness of Bacterioplankton Assemblage Richness in Seawater. Aquat. Microb. Ecol. 2001, 26 (2), 103-113.

(113) Galloway, T. S.; Cole, M.; Lewis, C. Interactions of Microplastic Debris throughout the Marine Ecosystem. Nat. Ecol. Evol. 2017, 1, 0116.

(114) Davey, M. E.; O’Toole, G. A. Microbial Biofilms: From Ecology to Molecular Genetics. Microbiol. Mol. Biol. Rev. 2000, 64 (4), $847-867$.

(115) Nadell, C. D.; Foster, K. R.; Xavier, J. B. Emergence of Spatial Structure in Cell Groups and the Evolution of Cooperation. PLoS Comput. Biol. 2010, 6 (3). e1000716.

(116) Nadell, C. D.; Drescher, K.; Foster, K. R. Spatial Structure, Cooperation and Competition in Biofilms. Nat. Rev. Microbiol. 2016, 14 (9), 589-600.

(117) Gewert, B.; Plassmann, M.; Sandblom, O.; Macleod, M. Identification of Chain Scission Products Released to Water by Plastic Exposed to Ultraviolet Light. Environ. Sci. Technol. Lett. 2018, 5, 272276.

(118) Wright, R. J.; Bosch, R.; Gibson, M. I.; Christie-Oleza, J. A. Plasticizer Degradation by Marine Bacterial Isolates: A Proteogenomic and Metabolomic Characterization. Environ. Sci. Technol. 2020, 54 (4), 2244-2256.

(119) Enke, T. N.; Leventhal, G. E.; Metzger, M.; Saavedra, J. T.; Cordero, O. X. Microscale Ecology Regulates Particulate Organic Matter Turnover in Model Marine Microbial Communities. Nat. Commun. 2018, 9 (2743), 1-8.

(120) Enke, T. N.; Datta, M. S.; Schwartzman, J.; Cermak, J.; Schmitz, D.; Barrere, J.; Pascual-garcia, A.; Cordero, O. X. Modular Assembly of Polysaccharide- Degrading Marine Microbial Communities. Curr. Biol. 2019, 29, 1-8.

(121) Van Sebille, E.; Wilcox, C.; Lebreton, L.; Maximenko, N.; Hardesty, B. D.; Van Franeker, J. A.; Eriksen, M.; Siegel, D.; Galgani, F.; Law, K. L. A Global Inventory of Small Floating Plastic Debris. Environ. Res. Lett. 2015, 10 (12), 1-11.

(122) Holmström, A. Plastic Films on the Bottom of the Skagerack. Nature 1975, 255, 622-623.

(123) Ye, S.; Andrady, A. L. Fouling of Floating Plastic Debris under Biscayne Bay Exposure Conditions. Mar. Pollut. Bull. 1991, 22 (12), 608-613.

(124) Fazey, F. M. C.; Ryan, P. G. Biofouling on Buoyant Marine Plastics: An Experimental Study into the Effect of Size on Surface Longevity. Environ. Pollut. 2016, 210, 354-360. 
(125) Kaiser, D.; Kowalski, N.; Waniek, J. J. Effects of Biofouling on the Sinking Behavior of Microplastics. Environ. Res. Lett. 2017, 12, 124003.

(126) Chubarenko, I.; Bagaev, A.; Zobkov, M.; Esiukova, E. On Some Physical and Dynamical Properties of Microplastic Particles in Marine Environment. Mar. Pollut. Bull. 2016, 108 (1-2), 105-112.

(127) Lagarde, F.; Olivier, O.; Zanella, M.; Daniel, P.; Hiard, S.; Caruso, A. Microplastic Interactions with Freshwater Microalgae: Hetero-Aggregation and Changes in Plastic Density Appear Strongly Dependent on Polymer Type. Environ. Pollut. 2016, 215, 331-339.

(128) Frère, L.; Paul-Pont, I.; Moreau, J.; Soudant, P.; Lambert, C.; Huvet, A.; Rinnert, E. A. Semi-Automated Raman Micro-Spectroscopy Method for Morphological and Chemical Characterizations of Microplastic Litter. Mar. Pollut. Bull. 2016, 113 (1-2), 461-468.

(129) Erni-Cassola, G.; Gibson, M. I.; Thompson, R. C.; ChristieOleza, J. A. Lost, but Found with Nile Red: A Novel Method for Detecting and Quantifying Small Microplastics (1 Mm to $20 \mathrm{Mm}$ ) in Environmental Samples. Environ. Sci. Technol. 2017, 51 (23), 1364113648 .

(130) Phuong, N. N.; Zalouk-Vergnoux, A.; Poirier, L.; Kamari, A.; Châtel, A.; Mouneyrac, C.; Lagarde, F. Is There Any Consistency between the Microplastics Found in the Field and Those Used in Laboratory Experiments? Environ. Pollut. 2016, 211, 111-123.

(131) Choy, C. A.; Robison, B. H.; Gagne, T. O.; Erwin, B.; Firl, E.; Halden, R. U.; Hamilton, J. A.; Katija, K.; Lisin, S. E.; Rolsky, C.; S. Van Houtan, K. The Vertical Distribution and Biological Transport of Marine Microplastics across the Epipelagic and Mesopelagic Water Column. Sci. Rep. 2019, 9 (1), 1-9.

(132) Woodall, L. C.; Jungblut, A. D.; Hopkins, K.; Id, A. H.; Robinson, F.; Gwinnett, C.; Paterson, G. L. J Deep-Sea Anthropogenic Macrodebris Harbours Rich and Diverse Communities of Bacteria and Archaea. PLoS One 2018, 13, 1-11.

(133) Courtene-Jones, W.; Quinn, B.; Gary, S. F.; Mogg, A. O. M.; Narayanaswamy, B. E. Microplastic Pollution Identified in Deep-Sea Water and Ingested by Benthic Invertebrates in the Rockall Trough, North Atlantic Ocean. Environ. Pollut. 2017, 231, 271-280.

(134) Cole, M.; Lindeque, P. K.; Fileman, E.; Clark, J.; Lewis, C.; Halsband, C.; Galloway, T. S. Microplastics Alter the Properties and Sinking Rates of Zooplankton Faecal Pellets. Environ. Sci. Technol. 2016, 50 (6), 3239-3246.

(135) Zhao, S.; Ward, J. E.; Danley, M.; Mincer, T. J. Field-Based Evidence for Microplastic in Marine Aggregates and Mussels: Implications for Trophic Transfer. Environ. Sci. Technol. 2018, 52 (19), 11038-11048.

(136) Coppock, R. L.; Galloway, T. S.; Cole, M.; Fileman, E. S.; Queirós, A. M.; Lindeque, P. K. Microplastics Alter Feeding Selectivity and Faecal Density in the Copepod, Calanus Helgolandicus. Sci. Total Environ. 2019, 687, 780-789.

(137) Porter, A.; Smith, K. E.; Lewis, C. The Sea Urchin Paracentrotus Lividus as a Bioeroder of Plastic. Sci. Total Environ. 2019, 693, 133621.

(138) Long, M.; Moriceau, B.; Gallinari, M.; Lambert, C.; Huvet, A.; Raffray, J.; Soudant, P. Interactions between Microplastics and Phytoplankton Aggregates: Impact on Their Respective Fates. Mar. Chem. 2015, 175, 39-46.

(139) Long, M.; Paul-Pont, I.; Hégaret, H.; Moriceau, B.; Lambert, C.; Huvet, A.; Soudant, P. Interactions between Polystyrene Microplastics and Marine Phytoplankton Lead to Species-Specific Hetero-Aggregation. Environ. Pollut. 2017, 228, 454-463.

(140) Michels, J.; Stippkugel, A.; Wirtz, K.; Engel, A. Aggregation of Microplastics with Marine Biogenic Particles. Proc. R. Soc. B 2018, 285, 1-9.

(141) Porter, A.; Lyons, B. P.; Galloway, T. S.; Lewis, C. Role of Marine Snows in Microplastic Fate and Bioavailability. Environ. Sci. Technol. 2018, 52 (12), 7111-7119.

(142) Cunha, C.; Faria, M.; Nogueira, N.; Ferreira, A.; Cordeiro, N. Marine vs Freshwater Microalgae Exopolymers as Biosolutions to Microplastics Pollution. Environ. Pollut. 2019, 249, 372-380.
(143) de Haan, W. P.; Sanchez-Vidal, A.; Canals, M. Floating Microplastics and Aggregate Formation in the Western Mediterranean Sea. Mar. Pollut. Bull. 2019, 140 (January), 523-535.

(144) Restrepo-Flórez, J.-M.; Bassi, A.; Thompson, M. R. Microbial Degradation and Deterioration of Polyethylene - A Review. Int. Biodeterior. Biodegrad. 2014, 88, 83-90.

(145) Krueger, M. C.; Harms, H.; Schlosser, D. Prospects for Microbiological Solutions to Environmental Pollution with Plastics. Appl. Microbiol. Biotechnol. 2015, 99 (21), 8857-8874.

(146) Yoshida, S.; Hiraga, K.; Takehana, T.; Taniguchi, I.; Yanaji, H.; Maeda, Y.; Toyohara, K.; Miyamoto, K.; Kimura, Y.; Oda, K. A Bacterium That Degrades and Assimilates Poly(Ethyleneterephthalate). Science (Washington, DC, U. S.) 2016, 351 (6278), 1196-1199.

(147) Danso, D.; Zimmermann; Schmeisser, C.; Chow, J.; Zimmermann, W.; Wei, R.; Leggewie, C.; Li, X.; Hazen, T.; Streit, W. R. New Insights into the Function and Global Distribution of Polyethylene Terephthalate (PET) Degrading Bacteria and Enzymes in Marine and Terrestrial Metagenomes. Appl. Environ. Microbiol. 2018, 84 (8), e02773-17.

(148) Andrady, A. L. Microplastics in the Marine Environment. Mar. Pollut. Bull. 2011, 62 (8), 1596-1605.

(149) Albertsson, A.-C.; Barenstedt, C.; Karlsson, S.; Lindberg, T. Degradation Product Pattern and Morphology Changes as Means to Differentiate Abiotically and Biotically Aged Degradable Polyethylene. Polymer 1995, 36 (16), 3075-3083.

(150) Royer, S.-J.; Ferron, S.; Wilson, S. T.; Karl, D. M. Production of Methane and Ethylene from Plastic in the Environment. PLoS One 2018, 13 (8), 1-13.

(151) Rummel, C. D.; Jahnke, A.; Gorokhova, E.; Kühnel, D.; Schmitt-Jansen, M. The Impacts of Biofilm Formation on the Fate and Potential Effects of Microplastic in the Aquatic Environment. Environ. Sci. Technol. Lett. 2017, 4 (7), 258-267.

(152) Zumstein, M. T.; Narayan, R.; Kohler, H.-P. E.; McNeill, K.; Sander, M. Dos and Do Nots When Assessing the Biodegradation of Plastics. Environ. Sci. Technol. 2019, 53 (17), 9967-9969.

(153) Neufeld, J. D.; Dumont, M. G.; Vohra, J.; Murrell, J. C. Methodological Considerations for the Use of Stable Isotope Probing in Microbial Ecology. Microb. Ecol. 2007, 53 (3), 435-442.

(154) Taipale, S. J.; Peltomaa, E.; Kukkonen, J. V. K.; Kainz, M. J.; Kautonen, P.; Tiirola, M. Tracing the Fate of Microplastic Carbon in the Aquatic Food Web by Compound-Specific Isotope Analysis. Sci. Rep. 2019, 9 (1), 1-15.

(155) Zadjelovic, V.; Chhun, A.; Quareshy, M.; Silvano, E.; Hernandez-Fernaud, J. R.; Aguilo-Ferretjans, M. M.; Bosch, R.; Dorador, C.; Gibson, M. I.; Christie-Oleza, J. A. Beyond Oil Degradation: Enzymatic Potential of Alcanivorax to Degrade Natural and Synthetic Polyesters. Environ. Microbiol. 2020, 00, 1-14.

(156) Groh, K. J.; Backhaus, T.; Carney-Almroth, B.; Geueke, B.; Inostroza, P. A.; Lennquist, A.; Leslie, H. A.; Maffini, M.; Slunge, D.; Trasande, L.; Warhurst, A. M.; Muncke, J. Overview of Known Plastic Packaging-Associated Chemicals and Their Hazards. Sci. Total Environ. 2019, 651, 3253-3268.

(157) Hahladakis, J. N.; Velis, C. A.; Weber, R.; Iacovidou, E.; Purnell, P. An Overview of Chemical Additives Present in Plastics: Migration, Release, Fate and Environmental Impact during Their Use, Disposal and Recycling. J. Hazard. Mater. 2018, 344, 179-199.

(158) Teuten, E. L.; Rowland, S. J.; Galloway, T. S.; Thompson, R. C. Potential for Plastics to Transport Hydrophobic Contaminants. Environ. Sci. Technol. 2007, 41 (22), 7759-7764.

(159) Teuten, E. L.; Saquing, J. M.; Knappe, D. R. U.; Barlaz, M. A.; Jonsson, S.; Bjorn, A.; Rowland, S. J.; Thompson, R. C.; Galloway, T. S.; Yamashita, R.; Ochi, D.; Watanuki, Y.; Moore, C.; Viet, P. H.; Tana, T. S.; Prudente, M.; Boonyatumanond, R.; Zakaria, M. P.; Akkhavong, K.; Ogata, Y.; Hirai, H.; Iwasa, S.; Mizukawa, K.; Hagino, Y.; Imamura, A.; Saha, M.; Takada, H. Transport and Release of Chemicals from Plastics to the Environment and to Wildlife. Philos. Trans. R. Soc., B 2009, 364 (1526), 2027-2045. 
(160) Bakir, A.; Rowland, S. J.; Thompson, R. C. Competitive Sorption of Persistent Organic Pollutants onto Microplastics in the Marine Environment. Mar. Pollut. Bull. 2012, 64 (12), 2782-2789.

(161) Mato, Y.; Isobe, T.; Takada, H.; Kanehiro, H.; Ohtake, C.; Kaminuma, T. Plastic Resin Pellets as a Transport Medium for Toxic Chemicals in the Marine Environment. Environ. Sci. Technol. 2001, 35 (2), 318-324.

(162) Rochman, C. M.; Hoh, E.; Kurobe, T.; Teh, S. J. Ingested Plastic Transfers Hazardous Chemicals to Fish and Induces Hepatic Stress. Sci. Rep. 2013, 3 (3263), 1-7.

(163) González-Soto, N.; Hatfield, J.; Katsumiti, A.; Duroudier, N.; Lacave, J. M.; Bilbao, E.; Orbea, A.; Navarro, E.; Cajaraville, M. P. Impacts of Dietary Exposure to Different Sized Polystyrene Microplastics Alone and with Sorbed Benzo[a]Pyrene on Biomarkers and Whole Organism Responses in Mussels Mytilus Galloprovincialis. Sci. Total Environ. 2019, 684, 548-566.

(164) Vered, G.; Kaplan, A.; Avisar, D.; Shenkar, N. Using Solitary Ascidians to Assess Microplastic and Phthalate Plasticizers Pollution among Marine Biota: A Case Study of the Eastern Mediterranean and Red Sea. Mar. Pollut. Bull. 2019, 138, 618-625.

(165) Zimmermann, L.; Dierkes, G.; Ternes, T. A.; Völker, C.; Wagner, M. Benchmarking the in Vitro Toxicity and Chemical Composition of Plastic Consumer Products. Environ. Sci. Technol. 2019, 53 (19). 11467.

(166) Stahl, W. H.; Pessen, H. The Microbiological Degradation of Plasticizers. Appl. Microbiol. 1953, 1 (1), 30-35.

(167) Liang, D. W.; Zhang, T.; Fang, H. H. P.; He, J. Phthalates Biodegradation in the Environment. Appl. Microbiol. Biotechnol. 2008, 80 (2), 183-198.

(168) Kumar, V.; Sharma, N.; Maitra, S. S. Comparative Study on the Degradation of Dibutyl Phthalate by Two Newly Isolated Pseudomonas Sp. V21b and Comamonas Sp. 51F. Biotechnol. Reports 2017, 15, 1-10.

(169) Feng, N.; Yu, J.; Mo, C.; Zhao, H.; Li, Y.; Wu, B.; Cai, Q. Biodegradation of Di-n-Butyl Phthalate (DBP) by a Novel Endophytic Bacillus Megaterium Strain YJB3. Sci. Total Environ. 2018, 616-617, 117-127.

(170) Labrecque, L. V.; Kumar, R. A.; Davé, V.; Gross, R. A.; Mccarthy, S. P. Citrate Esters as Plasticizers for Poly(Lactic Acid). J. Appl. Polym. Sci. 1997, 66 (8), 1507-1513.

(171) Wright, R. J.; Bosch, R.; Gibson, M. I.; Christie-Oleza, J. A. Plasticizer Degradation by Marine Bacterial Isolates: A Proteogenomic and Metabolomic Characterization. Environ. Sci. Technol. 2020, 54 (4). 2244.

(172) Huq, A.; Small, E. B.; West, P. A.; Huq, M. I.; Rahman, R.; Colwell, R. R. Ecological Relationships between Vibrio Cholerae and Planktonic Crustacean Copepods. Appl. Environ. Microbiol. 1983, 45 (1), 275-283.

(173) Song, J.; Jongmans-hochschulz, E.; Mauder, N.; Imirzalioglu, C.; Wichels, A.; Gerdts, G. Science of the Total Environment The Travelling Particles: Investigating Microplastics as Possible Transport Vectors for Multidrug Resistant E. Coli in the Weser Estuary (Germany). Sci. Total Environ. 2020, 720, 137603.

(174) Nyholm, S. V.; McFall-Ngai, M. J. The Winnowing: Establishing the Squid-Vibrios Symbiosis. Nat. Rev. Microbiol. 2004, 2 (8), 632-642.

(175) Horseman, M. A.; Surani, S. A Comprehensive Review of Vibrio Vulnificus: An Important Cause of Severe Sepsis and Skin and Soft-Tissue Infection. Int. J. Infect. Dis. 2011, 15, e157-e166.

(176) Jiao, S.; Chen, W.; Wang, E.; Wang, J.; Liu, Z.; Li, Y.; Wei, G. Microbial Succession in Response to Pollutants in Batch-Enrichment Culture. Sci. Rep. 2016, 6 (October 2015), 1-11.

(177) Sakib, S. N.; Reddi, G.; Almagro-Moreno, S. Environmental Role of Pathogenic Traits in Vibrio Cholerae. J. Bacteriol. 2018, 200 (15), $1-12$.

(178) Johnson, J. S.; Spakowicz, D. J.; Hong, B. Y.; Petersen, L. M.; Demkowicz, P.; Chen, L.; Leopold, S. R.; Hanson, B. M.; Agresta, H. O.; Gerstein, M.; Sodergren, E.; Weinstock, G. M. Evaluation of $16 \mathrm{~S}$
RRNA Gene Sequencing for Species and Strain-Level Microbiome Analysis. Nat. Commun. 2019, 10 (1), 1-11.

(179) Savoca, M. S.; Wohlfeil, M. E.; Ebeler, S. E.; Nevitt, G. A. Marine Plastic Debris Emits a Keystone Infochemical for Olfactory Foraging Seabirds. Sci. Adv. 2016, 2 (11), 1-9.

(180) Savoca, M. S.; Nevitt, G. A. Evidence That Dimethyl Sulfide Facilitates a Tritrophic Mutualism between Marine Primary Producers and Top Predators. Proc. Natl. Acad. Sci. U. S. A. 2014, 111 (11), 4157-4161.

(181) DeBose, J. L.; Nevitt, G. A. The Use of Odors at Different Spatial Scales: Comparing Birds with Fish. J. Chem. Ecol. 2008, 34 (7), 867-881.

(182) Savoca, M. S.; Tyson, C. W.; McGill, M.; Slager, C. J. Odours from Marine Plastic Debris Induce Food Search Behaviours in a Forage Fish. Proc. R. Soc. London, Ser. B 2017, 284, 20171000.

(183) Vroom, R. J. E.; Koelmans, A. A.; Besseling, E.; Halsband, C. Aging of Microplastics Promotes Their Ingestion by Marine Zooplankton. Environ. Pollut. 2017, 231, 987-996.

(184) Allen, A. S.; Seymour, A. C.; Rittschof, D. Chemoreception Drives Plastic Consumption in a Hard Coral. Mar. Pollut. Bull. 2017, 124 (1), 198-205.

(185) Rochman, C. M.; Browne, M. A.; Underwood, A. J.; Van Franeker, J. A.; Thompson, R. C.; Amaral-Zettler, L. A. The Ecological Impacts of Marine Debris: Unraveling the Demonstrated Evidence from What Is Perceived. Ecology 2016, 97 (2), 302-312. 